\title{
DO MANUSCRITO AO FOLHETO DE CORDEL: UMA LITERATURA ESCRITA PARA SER ORALIZADA
}

\author{
Maria Ignez Novais Ayala*
}

\begin{abstract}
Resumo: Considerações sobre a Literatura de Folhetos / Literatura de Cordel como uma literatura em processo, viva, que tem passado por várias mudanças, desde seu período de formação e produção de folhetos em vários estados do Nordeste. São destacados diferentes exemplos, dentre eles, os épicos manuscritos, colhidos por Euclides da Cunha durante a Guerra de Canudos, escritos para serem oralizados. O estudo centra-se na característica específica de ser uma literatura feita, mais para "os ouvidos" que para os olhos, desde o início, o que seria difícil de provar sem os estudos de vários pesquisadores e da leitura de folhetos existentes na coleção "Cordéis de Mário de Andrade". Esta coleção integra publicações de outros estados e de alguns países, em que se faz uso da mesma "fórmula editorial", identificada pelo tipo de edição em brochura, com capa de papel na cor branca ou colorido e miolo em papel jornal, mas contendo uma produção bem diferente do que se conhece como literatura de cordel. A coleção de Mário de Andrade também foi uma fonte fundamental para estudar a variação de denominações utilizadas pelos poetas populares nordestinos e, ainda, por fornecer o material que foi ponto de partida para dois ensaios de Mário de Andrade. Outra questão aqui desenvolvida diz respeito ao público tradicional constituído por leitores/ouvintes ou ouvintes/leitores, encontrados em pesquisas de campo, que trazem em sua memória uma ou mais histórias, publicadas em folhetos, decoradas, quando ainda eram crianças, mas que afloram sempre que surge uma oportunidade para "dizer" os versos ou cantá-los.
\end{abstract}

Palavras-chave: Literatura de cordel. Oralidade.

\begin{abstract}
Considerations on String Literature as literature in process, which has gone through several changes, since its initial production in several states in the Northeast. Various examples are highlighted, among them, the epic manuscripts collected by Euclides da Cunha during the Canudos war, written to be read aloud. The study focuses on the specific characteristic of being a literature aimed for the "ears" than for the eyes, since the beginning, which would be difficult to prove without the studies of several researchers on the string literature belonging to Mário de Andrade. This collection includes publications from other states and some countries, which make use of the same "editorial formula", identified by the kind of editing in brochure, with the cover of the paper in white or colored and in newsprint inside, but containing a very different production from what is known as string literature. The collection of Mário de Andrade was also a key source for studying the variation of designations used by the popular poets of the Northeast, as well as the starting point for two essays written by Mário de Andrade. Another aspect this text discusses concerns the traditional audience composed of readers/listeners or listeners/readers, found in field research, which bring in their memories one or more stories, published in brochures, decorated, when they were still children, but which emerge whenever there is an opportunity to "tell" the verses or sing them.
\end{abstract}

Keywords: String Literature. Oral Expression.

\section{Uma literatura escrita para ser oralizada}

Os autores não escrevem livros; não, eles escrevem textos que se tornam objetos escritos, manuscritos, gravados, impressos e, hoje, informatizados. Roger Chartier (1999, p. 17).

O período de 1893 a 1930 é considerado por TERRA (1983) como o momento de aparecimento da literatura que se firma no Nordeste e hoje é identificada como literatura de cordel. Os poemas têm por cenário a região marcada por fortes transformações econômicas, sociais e políticas, e, ainda, pelo flagelo da seca que, a partir de 1877, impulsionou levas de

\footnotetext{
* Pesquisadora Professora da UFPB, onde integra o corpo docente do Programa de Pós-Graduação em Linguística. É pesquisadora do CNPq desde 1988, com vários projetos concluídos e em andamento, dedicados à literatura e cultura brasileira, especialmente de tradição oral, muitos deles como bolsista nível 1 do CNPq. Atualmente, desenvolve várias atividades de pesquisa voltadas para o patrimônio imaterial brasileiro e de preservação de repertório de mestres tradicionais. Endereço eletrônico: ignez_ayala@uol.com.br
} 
migrantes a diferentes locais da região e aos seringais do Norte. Contingentes armados por policiais e por cangaceiros dominam a região Nordeste até 1938, ano da morte de Lampião. Neste espaço, espalham-se violência, mortes e surgem diferentes histórias que tematizam os horrores da seca, as disputas políticas, as ações de cangaceiros, transformadas em épicos populares, com fortes matizes romanescos, tal qual os feitos de cangaceiros Antônio Silvino e Lampião, que se transformaram em personagens, com atributos de honra ou de vingador. Também povoam a região, os beatos, destacando-se, como personagens dos poemas narrativos por seus milagres e por ter muitos seguidores. Assim são construídas as narrativas versadas por cantadores e poetas populares escritores de $\mathrm{ABCs}$, versos, histórias, folhetos, livros, livrinhos, conforme a denominação que variava da Bahia aos vários estados nordestinos. O público a que se destina esta literatura é diverso; a temática varia bastante - há poemas de crítica política e social, acompanhando os acontecimentos sociais (flagelo da seca, desigualdade, cangaceiros), além de poemas jocosos, com personagens cômicos. Ruth Brito Lêmos Terra assim se refere aos escritores:

Nos idos de 1893, quando o poeta Leandro Gomes de Barros passa a publicar seus poemas em folhetos, inicia-se a literatura popular impressa no Nordeste. Outros o seguirão: Francisco das Chagas Batista, que começa a publicar em 1902, e João Martins de Athayde em 1908.

É possível que anteriormente algum cantador ou poeta popular tenha impresso poemas. Mas Leandro foi sem dúvida o primeiro a produzir regularmente folhetos, possibilitando assim esta literatura em toda sua especificidade. Toma forma um conjunto de textos em permanente reedição. Tem início um processo peculiar de produção e comercialização e constituise um público para esta literatura. (TERRA, 1983, p. 17).

Por longo tempo estes escritos, impressos em pequenas brochuras, com dimensões aproximadas a um quarto de papel tamanho ofício, foram publicados em diferentes gráficas e tipografias nordestinas. Inicialmente, em tipografias de jornais e gráficas, aparecendo, depois, tipografias, cujos proprietários escreviam e publicavam seus livros e de outros poetas, além dos trabalhos frequentes das gráficas.

Esta literatura, em suas quatro décadas iniciais, caracteriza-se como uma épica popular, que alterna o trágico e o cômico, surgindo, num determinado espaço, ações de heróis como os cangaceiros, tratados como "bandido de honra" (Antônio Silvino), como "vingador" (Lampião), vilões, valentões (O valente Zé Garcia, José de Souza Leão), anti-heróis (João Grilo, Cancão de fogo), santos (os vários beatos com seus milagres, dentre os quais, Conselheiro, Beato Lourenço, Padre Cícero e Frei Damião), misturando-se realidade e imaginário.

Este caráter híbrido de sério-cômico das épicas dos folhetos de cordel é que vai ter longa duração na memória popular, presente nos clássicos desta literatura, que pouco descreve ambientes, mas narra muitas ações, mais próximas da realidade ou da ficção, da fantasia.

Os poemas narrativos passaram a ser lidos por diferentes públicos, tanto leitores individuais, quanto aqueles que recorriam à leitura socializada, isto é, quando as narrativas em verso ganhavam voz, através de algum leitor alfabetizado, que lia os poemas, em voz alta, dizendo ou cantando os versos para os ouvintes. O gosto pelos poemas-narrativos, desenvolvido por um público de leitura "de ouvido", formava multiplicadores, capazes de memorizar tanto as narrativas curtas, quanto as bem longas, que chegavam a 48 páginas impressas ou mais. Surgem, deste modo, uma espécie de homens-livro ${ }^{1}$, de mulheres e

\footnotetext{
1 Utilizo a expressão homem-livro, tomada de empréstimo do romance Fahrenheit 451, de Ray Bradbury, adaptando-a ao contexto nordestino, em que pessoas com uma memória extraordinária, guardam de cor, vários poemas narrativos originalmente publicados em folhetos, há várias décadas.
} 
crianças-livro, lendo, dizendo de cor ou cantando todos os versos, sem falhar. Desde sempre esses poemas narrativos, que são reconhecidos como folheto, histórias e romances, foram destinados a um público leitor/ouvinte ou ouvintes/leitores, procedimento que dá a peculiaridade desta literatura: a de ser uma literatura que se quer oral. A existência deste público leitor tradicional ainda hoje, comprova o hábito de ouvir ou cantar diante do público. (Retomarei esta questão mais adiante)

O sistema literário reconhecido como Literatura de Folhetos ou Literatura de Cordel, desde os seus momentos de formação, conserva muitos traços das práticas culturais tradicionais, em termos de experiências vivenciadas repassadas a ouvintes.

O espólio de Canudos, relatado por Euclides da Cunha em sua Caderneta de campo, revela os poemas toscamente manuscritos que narravam a ação dos combatentes durante as batalhas. José Calasans (1984) considera que esses manuscritos já tinham um modo de narrar que permaneceu na tradição oral de Canudos. Tratar da literatura de cordel na memória dos habitantes de Canudos forçosamente levou Calasans a retomar os livros de Euclides da Cunha - Cadernetas de campo (1975) e Os sertões (1985) - em que são referidos os poemas narrativos manuscritos obtidos por ele durante a Guerra de Canudos, da qual participou como repórter.

Em Canudos na Literatura de Cordel (1984), Calasans reúne um conjunto de ABCs e folhetos "selecionados porque representam tendências distantes do cordel brasileiro sobre o tema Canudos" (CALASANS, 1984, p. 3). Refere-se, aos poemas manuscritos que chegaram ao conhecimento de Euclides da Cunha e foram por ele reunidos e copiados, em 1897, em sua Caderneta de campo (CUNHA, 1975, p. 58-61), no próprio campo de batalha, a Guerra de Canudos ${ }^{2}$ :

[...] Foi ele [Euclides da Cunha] a única testemunha da tragédia a considerar a contribuição do bardo anônimo para a interpretação dos sentimentos populares de referência às atividades do Bom Jesus Conselheiro. Podemos também apontá-lo como um dos primeiros ensaístas brasileiros a julgar válidas as fontes orais para elaboração da história dos povos. [...]

Euclides da Cunha citou [em Os sertões] sete quadras dos dois ABCs que chegaram ao seu conhecimento e foram por ele copiados na Caderneta de campo. Julgamos que as citadas composições teriam sido as primeiras obras completas da poesia popular sobre o "conselheirismo" e, portanto, precederam os trabalhos de literatura de cordel aqui e agora reunidos na presente publicação.

$\mathrm{O}$ segundo dos $\mathrm{ABCs}$ copiados por Euclides da Cunha, o $A B C d a$ Incredulidade, "contava como se dera a morte do coronel Moreira César e a derrota completa da tropa por ele comandada, em março de 1897." (CALASANS, 1984, p. 3).

Este $\mathrm{ABC}$ está escrito em sextilhas, com sete sílabas métricas e rima nos versos pares, como se faz até hoje. A escrita está mais próxima da fala, o que causou dificuldade ao escritor, ao copiar os versos (e ao editor da Caderneta) pois há algumas imprecisões como, por exemplo, versos que não rimam, provavelmente resultantes do não entendimento da caligrafia:

Daonde hé este homem

tão chêo di valentia

\footnotetext{
2 Retomo aqui, trechos de ABC, Folheto, Romance ou Verso: a literatura impressa que se quer oral. Graphos. João Pessoa, Vol. 12, N. 2, Dez./2010, p. 52-73 - ISSN 1516-1536. Disponível em:

http://periodicos.ufpb.br/index.php/graphos/article/viewFile/10908/6113 Último acesso em 29 nov. 2016
} 
q. vem araza sidade

di manham athe meio-dia

Quanta fera os urubu ${ }^{3}$

Coele fizeram fubá (grifo meu)

Comparando o texto copiado por Euclides da Cunha com a versão do $\mathrm{ABC}$ da incredulidade publicada por José Aras no livro Sangue de irmãos (1963) que "traz o nome de Manuel dos Santos, provavelmente o informante" (CALASANS, 1984, p. 3), tem-se uma prova da permanência na memória de versos sobre experiência vivenciada por participantes que conseguiram sobreviver ao massacre e os repassaram a outros:

Donde saiu esse home

Cum tamanha soberbia

Quiria arrasá a cidade

De manhã até mei dia

Quinta feira os arubú

Cum ele fizero fulia.

Como se pode observar o sentido geral se mantém, com pouca alteração. Os urubus, presentes no exemplo acima, aparecem em várias estrofes deste $\mathrm{ABC}$, tanto na versão copiada por CUNHA, quanto por ARAS. Este poema narra a derrota sofrida pela expedição do general Moreira César numa perspectiva dos conselheiristas. Estruturas formulares do tipo "mais ozurubu comeo", "[lembrança] que o zurubu mandou", "veio dar carne aos zurubú" na versão de CUNHA, mantêm-se na versão de ARAS e até se ampliam, criando imagens da crueza da luta, morte dos poderosos e força dos sertanejos. Ainda não são os vencidos.

Calasans reproduz o folheto A Guerra de Canudos de João Melchíades Ferreira, poeta paraibano conhecido como o Cantor da Borborema, que lutou em Canudos, mas escreveu depois, em 1904, início do Século XX. Embora fizesse parte de um dos batalhões, não escreveu na perspectiva dos vencedores. Neste folheto de João Melchíades tem-se o narrar da experiência de quem vivenciou o acontecimento e o verbalizou tempos depois com força poética. No trecho, após o episódio em que Moreira César levou um balaço, morreu e o exército bate em retirada, aparecem os versos, sobre a luta:

Deu coragem aos jagunços

Que ao ouvir tocar retirada

Correram pelas veredas

Empiquetando a vanguarda

Abandonaram os feridos

Disparou toda brigada

[...]

Escapa, escapa, soldado

Quem tiver perna que corra

Quem quiser ficar que fique

Quem quiser morrer que morra

Há de nascer duas vezes

Quem sair desta gangorra.

\footnotetext{
${ }^{3} \mathrm{Na}$ fotografia, do manuscrito, que ilustra a edição da Caderneta entre a página 58 e 59, embora meio apagado, com lupa se lê "Quinta fêra os zurubu/Coelle fizeram fulia".
} 
Esta estrofe citada mimetiza a força da batalha, o zumbido das balas e a dinâmica dos ataques dos revoltosos através das sibilantes e oclusivas em abundância, numa das estrofes antológicas desta literatura.

Os exemplos aqui citados, dos manuscritos colhidos por Euclides da Cunha, passando pelos versos colhidos por Calasans na Bahia e chegando ao folheto de João Melchíades Ferreira permitem perceber que a escrita é um suporte da oralidade.

João Melchíades Ferreira, o "Cantor da Borborema", era cantador de viola e escritor de folhetos que se tornaram clássicos, reconhecido como um dos pioneiros, ao lado de Leandro Gomes de Barros, Chagas Batista, José Adão Filho e João Martins de Athayde, teve sucesso em vendagem de folhetos e reconhecimento em vida. Morreu em 1933, antes da polêmica da autoria de $O$ pavão mysterioso, que envolveu o seu nome.

Naquele tempo a poesia narrativa tinha vida intensa no Nordeste, tanto na voz de quem lia, quanto do público leitor/ouvinte ou ouvinte/leitor. Esta poesia popular nordestina impressa em folhetos, até a década de 1930 caracteriza-se como uma épica ${ }^{4}$ popular, que conservou seu sentido etimológico de palavra dita e cantada, mesmo quando escrita. Mesmo quando escrita, destinava-se para se fazer uso da palavra, dita ou cantada. A voz não era dispensada nem o canto, que auxiliava a memorização. Sem sombra de dúvidas, trata-se de uma literatura escrita para ser oralizada. Muitos dos autores cantavam seus poemas narrativos em suas apresentações, em cantoria, acompanhados pela viola, mudando a toada, mais rápida ou mais ligeira, de acordo com as ações dos personagens, poeticamente narradas, conforme me explicaram vários cantadores e escritores de folheto.

\section{A difícil ordem dos livros}

Trata-se, a meu ver, de uma literatura em que é difícil estabelecer "a ordem dos livros", pois, como nos ensina Chartier (A ordem dos livros, 1999), os escritores fazem textos; outros profissionais cuidam da editoração (revisão de texto, ilustração, tamanho dos tipos, dimensões da publicação, capa, distribuição, venda etc.). A ordem dos livros, isto é, das publicações é apontada por Ruth Brito Lêmos Terra, citada acima, a partir de Leandro Gomes de Barros. No entanto, é preciso lembrar que há também uma documentação manuscrita, como os ABCs colhidos por Euclides da Cunha em Canudos, que se referem à ação real da luta e resistência dos beatos de Antônio Conselheiro e as derrotas dos militares, apresentando várias características desta literatura impressa em formação.

No nosso caso em estudo, o que torna complexa a tarefa de definir esta literatura popular nordestina é a existência de um conjunto de sistemas poéticos orais para cantar que se articulam, os quais apresentam similaridade na rima, na métrica e na maneira de compor as estrofes, em sua maioria, sextilhas com sete sílabas métricas, rimando nos versos pares. Há também uso de septilhas, nos poemas narrativos impressos e nos orais, como há também décimas e estrofes dialogadas; a maior variedade destes esquemas rímicos e métricos aparecem nos gêneros do repente. Esta variedade de modos de rimar aparece nos folhetos ou cordéis, quando narram o encontro de dois personagens fictícios que se desafiam, de repentistas em embate nas cantorias, no geral imaginárias, e em alguns casos, como uma criação a partir de uma cantoria lendária, sempre lembrada, não importando se existiu ou não de fato. Também aparecem nos poemas e canções, que colecionei entre 1970 e 1980, que eram publicados em recortes de papel de capa de folheto que sobravam nas gráficas populares que os produziam.

\footnotetext{
${ }^{4}$ A palavra épica, tomada no sentido etimológico - do grego, formada por "epos" (= o que se narra pela palavra; palavra ou discurso poético cantado) + sufixo "iko" (= relativo a), resultando em poesia oral e cantada.
} 
Os poetas populares, mencionados por TERRA, na citação acima, ganharam outras denominações ao longo da história desta literatura: poetas de bancada, escritores de folheto ou, ainda, cordelistas. Escrevem poemas narrativos de diferentes gêneros, para serem ouvidos em diferentes sistemas poéticos orais, o que resulta em trazer para esta literatura escrita vários gêneros desenvolvidos por diferentes tipos de cantadores, isto é, repentistas em cantorias em residências e em locais públicos, como feiras e mercados, espaços abertos, onde se aglomera bastante gente. Este espaço das feiras e mercados também era frequentado por duplas de emboladores de coco, que, por sua vez tem seus gêneros, ritmos e modos de rimar e cantar específicos. Coexistem, portanto, nestes poemas escritos e impressos em folhetos, traços de diferentes sistemas poéticos orais, que se fundem e dão início aos gêneros desta literatura de cordel. A literatura de cordel constituída por textos escritos, desde o início de sua história, pôde ter os folhetos/cordéis oralizados, isto é, quando os poemas são apresentados, diante de um público, ditos, declamados ou cantados. Ao longo de sua história, a literatura de cordel tem passado por diferentes tipos de oralização. Hoje é comum a performance de atores ou de alunos, estes últimos em exercícios sugeridos na escola. Entre as décadas de 1960 e 1970, pesquisadores os encontraram apresentados por folheteiros, nome atribuído ao vendedor de folhetos em feiras-livre, que também podia acumular as funções de escritor e editor de suas narrativas. Paralelo a este sistema literário escrito, que se servia da oralidade para a venda dos livrinhos e para o prazer dos ouvintes/leitores, existem, no Nordeste, até hoje, os sistemas poéticos orais cantados - o do coco ou embolada, o do repente e o do aboio - cada qual, com uma vastidão de temas, motivos e histórias, ficcionais ou vivenciadas, passando, cada qual, por ressignificações.

Muitos destes poemas que pertencem a estas diferentes "séries" orais - coco, repente e aboio - foram tematizados pela literatura de cordel, como, por exemplo, $O$ coco do boi tungão, A história do pinto pelado, que trazem para o interior desta literatura impressa recriações com base em poemas narrativos tradicionais, ajustados aos cânones do folheto. Os poemas narrativos conhecidos como poemas e canções de vaquejada são gêneros relacionados com o aboio, atividade, que originalmente foi canto de trabalhado e passou a gênero oral, também veiculado por escrito, publicado em folhas soltas, entre 1970 e 1980, e, depois passou a ser editado em fitas cassete e, mais recentemente em CDs e DVDs. Os cantadores, cantadores de viola, violeiros ou repentistas são responsáveis por outro sistema poético oral em que há, ainda, um desafio entre as capacidades de improvisar e de ganhar a aceitação do público ${ }^{5}$. No início da literatura de cordel, eles traziam os poemas, publicados ou ainda manuscritos, para dentro das cantorias. Estes poemas eram cantados nesses encontros, revezando-se romances com desafios, os improvisos ou repentes. Por volta dos anos 1970, os poemas publicados em folhetos passaram a ser substituídos pelos poemas curtos, veiculados também por escrito, em folhas soltas: são os chamados poemas e canções.

Embora apresentados de um modo muito resumido, é possível perceber que se trata de, pelo menos, quatro sistemas poéticos orais que se misturam: 1) do coco ou coco de embolada (sistema de poesia improvisada oral, das duplas de emboladores, que criam variações a partir de versos tradicionais que se embolam, em ritmo próprio, acompanhado por ganzá ou pandeiro); 2) da cantoria (sistema poético oral caracterizado por gêneros do repente e por gêneros poéticos orais/escritos, isto é, escritos para serem oralizados, apresentados em alternância com os baiões do improviso ${ }^{6}$ ); 3 ) do aboio (sistema poético oral, manuscrito ou impresso para ser oralizado, que, antes, era o canto de trabalho do vaqueiro e, depois, tornou-

\footnotetext{
5 A respeito das formas de improviso e dos poemas e canções cantados pelos repentistas, consultar AYALA (1988).

6 Baião, baião de viola - dá-se o nome de baião de viola, aos acordes de viola de cada repentista. Entretanto "a denominação ultrapassou os limites instrumentais, tornando-se a designação das sequências do improviso que formam as unidades da cantoria”. (AYALA, 1988, p. 25).
} 
se um tipo de canção que narra a vida de vaqueiros, em que, entre estrofes, geralmente são cantados aboios semelhantes ao de campo, feito por vaqueiros para juntar a boiada); 4) da literatura de cordel, publicado em folheto (sistema poético escrito para ser oralizado, com poemas narrativos, com muitos gêneros, os mais longos denominados histórias e romance, da literatura de cordel, como O pavão misterioso). Conforme Azulão (João José dos Santos), estes poemas eram cantados nas cantorias, substituídos, depois, pelos poemas e canções, gêneros poéticos narrativos, de curta extensão, os chamados poemas e canções, ao passo que os de cordel eram longos, demorando bastante tempo para serem cantados. Conta Azulão que, antes, este poema, $O$ pavão misterioso, era manuscrito e, decorado por seu autor, José Camelo de Melo Rezende, era cantado por ele, nas cantorias, acompanhado por melodia e ponteios feitos na viola por ele e seu companheiro, Romano Elias. Só passou a ser impresso depois, para não se confundir com a $O$ pavão mysterioso, de João Melchíades Ferreira, que foi acusado de plágio, com base em cópia recebida de Romano Elias. Segundo Azulão, José Camelo não publicava o folheto e todos que queriam ouvir este poema, o convidavam para cantar nas cantorias. Nessas cantorias, Romano Elias era o cantador que fazia dupla com ele. De tanto ouvir José Camelo cantar, Romano decorou, se apropriou da história original, criou sua versão, passou para João Melchíades Ferreira, que a publicou em folheto, Este folheto, com autoria de João Melchíades, logo teve um sucesso de venda. Isto causou grande desgosto a José Camelo, que passados muitos anos, conseguiu restituir a autoria do romance $O$ pavão misterioso. Esta história sobre a autoria do $O$ pavão misterioso, Azulão me contou em uma entrevista, feita em João Pessoa, em 2001, registrada em vídeo, de que resultou Azulão: a voz do folheto (2007) que até hoje conta com pequena circulação, em algumas cópias em DVD.

Embora muitos gêneros destes sistemas poéticos nordestinos circulem por escrito, impressos ou manuscritos, ou apenas memorizados, eles carregam em si certa semelhança, devido à rima, métrica e tipos de estrofe. Até estudiosos se confundem, às vezes, classificando poemas e canções com os gêneros do folheto ou cordel, por serem impressos em sobra de papel usado para capa ou página dos folhetos, com esquemas de rimas e estrofes semelhantes. É preciso estar atento, pois, mesmo utilizando os mesmos suportes de divulgação publicados como folheto de cordel, livros, como gravações sonoras (em fitas cassete ou CDs) e audiovisuais (em filmes e DVDs) há gêneros poéticos que pertencem a diferentes "séries" documentais da literatura popular em verso nordestina.

Esta questão de mais de um poema publicados em um folheto, livro de versos ou livrinho entre as décadas de 1910 e 1930 ficarão mais fáceis de se entender com exemplos de coleções antigas, como a de Mário de Andrade e outras, existentes no Instituto de Estudos Brasileiros.

Mauro W. B. de Almeida fez várias entrevistas com escritores de folheto que revelaram a ele normas de composição dos poemas narrativos para serem publicados como folhetos de cordel. São várias regras para começar a narrativa, para introduzir novos episódios, sempre atentos à possível reação do público, retardando o desfecho, através da suspensão da ação principal e introdução de novas sequências de ação, pensando em como será o desfecho, sem perder de vista a quantidade de páginas impressas. Acompanhemos uma das observações de Mauro Almeida:

[...] o folheto é um objeto para ser usado. Todos sabemos como utilizar um livro, isto é, lendo-o em solidão e em silêncio[...] Se a literatura de folhetos difere centralmente da "outra", é principalmente nesse modo de usar: ela é ouvida, e coletivamente. Na verdade, esse aspecto é pouco visível. Nunca li uma descrição de leitura de folheto, e não assisti a nenhuma. O que digo é baseado em informação fornecida por antigos consumidores dessa literatura, hoje poetas, vendedores ou editores[...]. (ALMEIDA, 1979). 
Outra pesquisadora, Julie Cavignac, constatou, anos mais tarde:

[...] raras eram as pessoas que não podiam reproduzir os versos, recitar trechos de cantorias ou de romances, cantar uma canção se acompanhando a um instrumento. [...] A evocação dos relatos, das lembranças dos folhetos, feita confidencialmente, sempre levava de volta à infância, ao tempo de aprendizagem da leitura, ao trabalho em família, à vida nos sítios. (CAVIGNAC, 2006)

Os chamados poemas e canções que eram vendidos nas bancas de poetas em feiras e mercados, nos anos 1970/1980, comprados por quem queria decorá-los ou cantá-los, devem ser classificados como gêneros híbridos, orais, quando divulgados em cantoria e escritos, quando impressos, vendidos em bancas de folheteiros. Com a indústria de discos, abrindo-se para as poéticas orais nordestinas surgem no início dos anos 1970, discos de cantadores de viola, de emboladores, de poemas cantados ou declamados, de canções e, também, de aboiadores. Mais raros são os discos contendo poemas da literatura de cordel, cantados ou declamados. Os discos de cantadores, emboladores e aboiadores foram sucedidos por fitas cassete e, posteriormente, pela edição de CDs. As folhas soltas, que continham poemas e canções, deixaram de ser impressas nos restos de papel colorido utilizado para a produção das capas dos folhetos e hoje constam da coleção de raros pesquisadores que se interessaram por estas publicações.

Estabelecido um quadro geral dos sistemas poéticos nordestinos, cabe pensar na "ordem dos livros". Como estabelecer a ordem dos textos publicados em folhetos, em livros, em discos, em CDs, em DVDs, em programas de TV, em filmes? Por sistemas poéticos orais, escritos, híbridos, comportando uma forma impressa para ser oralizado? Este tipo de classificação, até onde vai meu conhecimento, dificilmente será feita.

Por títulos, por autores, por temas e motivos, foram várias as tentativas de estabelecer ordem para os livros populares, denominados no Nordeste por ABC (na Bahia), versos, livro, folhetos, romances e cordel, pelos estudiosos. Se consultarmos a bibliografia, veremos que entre os anos 1960 e 1970, os pesquisadores da Fundação Casa de Ruy Barbosa utilizaram a terminologia "literatura popular em verso" em diversas publicações, passando, mais recentemente, a literatura de cordel, cordel cordéis. Esta instituição, em Literatura popular em verso - Catálogo (1961) e Literatura popular em verso - Antologia (1964), organizados por Manoel Cavalcanti Proença a partir de três coleções (a maioria dos folhetos existente na coleção do próprio Cavalcanti Proença, alguns de Orígenes Lessa e de Manuel Diégues Jr.) indicava, detalhadamente, os critérios para a catalogação e edição dos folhetos, como número que cada folheto recebia na coleção, título, o nome do autor, editor-proprietário e usava uma convenção que continha o primeiro, o décimo e último verso. Se havia acróstico era indicado na ficha catalográfica. Tal cuidado, deve-se à existência de mais de um autor, ou de autor que deixou de ser citado, passando a figurar só o do editor proprietário ou, em caso de plágio, a recuperação de autoria, evidenciada pelo acróstico do autor do poema ou de advertência publicada na quarta-capa ou nos primeiros versos do poema. São várias as estratégias utilizadas pelos autores, que faziam questão do respeito à autoria e não admitiam qualquer forma de apropriação. Na Introdução à Antologia, Manoel Cavalcanti Proença informa que folhetaria era o nome dado às casas que vendiam os folhetos; folheteiro era o vendedor. Quanto aos poemas informa:

A denominação genérica de História se vai impondo e substituindo a antiga de Romance. E isso se pode ver, algumas vezes em reedições de velhos poemas, onde ocorre estar na capa a denominação de História, e a de 
Romance no título interno ou no primeiro verso [...]. (CAVALCANTI PROENÇA, 1964, p. 2).

Outras instituições de pesquisa fizeram suas listas de cordel por título, por autor, adotando os procedimentos semelhantes aos da Casa de Ruy Barbosa ou, então, passaram a adotar os critérios da ABNT para livros.

Seja qual for a série documental a que pertencem, esses poemas quando chegam ao público, literalmente ganham corpo e voz ao serem recitados ou cantados. Alguns leitores/ouvintes têm certos poemas como seus, pois estão "dentro de suas cabeças", estão verso a verso na sua memória. Antes de passar a quem dá voz dos folhetos, visitemos, ainda que rapidamente a Coleção "Cordéis de Mário de Andrade", do Instituto de Estudos Brasileiros.

\section{Mário de Andrade7, os folhetos nordestinos e outros com a mesma "fórmula editorial"}

Roger Chartier, comparou a literatura de cordel com outros impressos que se assemelhavam pela "fórmula editorial" (CHARTIER, 2002), isto é, pelo tipo de publicação feita com papel barato, nas mesmas dimensões, o que vale dizer que a comparação se deu pelo tipo de edição, de projeto editorial adotado.

Já na primeira metade do Século XX, presencia-se o surgimento de uma crítica externa, fora da região e do sistema que valoriza esta literatura popular como sistema literário autônomo e capta a relação oral/escrito existente nestes poemas narrativos impressos e sua forte ligação com a cultura nordestina, especialmente do sertão, a representação da vida, valores, visão de mundo, conflitos e desigualdades, além de temas literários adaptados da literatura escrita que foram aclimatados à região e ajustados às normas desta literatura.

Mário de Andrade é um dos escritores que se encantou com a literatura popular em versos nordestina, tanto dos cantadores, quanto dos escritores de folhetos. Vou me referir a dois ensaios publicados em $O$ baile das quatro artes (ANDRADE, 1963). Inicio por "O artista e o artesão", aula inaugural dos cursos de Filosofia e História da Arte, do Instituto de Artes da Universidade do Distrito Federal, Rio de Janeiro, em 1938, em que estabeleceu uma comparação entre o artista e o artesão:

... Que a arte na realidade não se aprende. Existe, é certo, dentro da arte, um elemento, o material, que é necessário pôr em ação, mover pra que a obra de arte se faça. $\mathrm{O}$ som em suas múltiplas maneiras de se manifestar, a cor, a pedra, o lápis, o papel, a tela, a espátula, são o material de arte que o ensinamento facilita muito a pôr em ação. [...]

$\mathrm{O}$ artesanato, os segredos, os caprichos, as exigências do material, isto é assunto ensinável, e de ensinamento por muitas partes dogmático [...] E si um artista é verdadeiramente artista, quero dizer, está consciente do seu destino e da missão que se deu para cumprir no mundo, ele chegará fatalmente àquela verdade de que, em arte, o que existe de principal é a obra de arte. (ANDRADE, 1963, p. 11).

O outro ensaio selecionado é O romanceiro de Lampeão, publicado na Revista Nova de São Paulo, com o pseudônimo de Leocádio Pereira, em 1932:

\footnotetext{
${ }^{7}$ Foi respeitada a grafia de Mário de Andrade, que tinha como proposta deixar marcas da oralidade no texto, como por exemplo, "pra, si...".
} 
"O cantador nordestino tem duas formas principais de poesia cantada: o Desafio e o Romance. O primeiro é a forma dialogada, em uso sempre que dois ou mais cantadores se encontram; é a que mais se presta à improvisação. Porém mesmo no Desafio grande número de estrofes surgidas como de improviso são, na realidade, estrofes decoradas, extraídas da abundantíssima literatura de cordel nordestina. O Romance é a forma solista por excelência, poesia historiada, relatando fatos do dia. Qualquer caso mais ou menos impressionante sucedido no Brasil, e às vezes até mesmo no estrangeiro, é colhido nos jornais por algum poeta popular praceano, versificado e impresso em folheto. $\mathrm{O}$ cantador rural, a infinita maioria das vezes analfabeto, decora o folheto, com auxílio de algum intermediário alfabetizado, e lá se vai cantando o romance, brejo, caatinga e sertão afora". (ANDRADE, 1963, p. 87, grifos meus).

\section{Cita trecho do folheto História do Capitão Lampeão e comenta:}

"É o encontro de maravilhas como essa que compensam o estudo da literatura de cordel... Mas o exímio colocador de pronomes desse romance, produziu realmente uma peça interessantíssima pelos assuntos tradicionais com que bordou a sua história. Nele vêm a descrição de indivíduos façanhudos tão peculiar aos desafios nordestinos; a luta de Lampeão com o Diabo, mito de Orfeu tão universalizado e que é absolutamente geral na tradição dos cantadores nordestinos; e a descrição do Marco de Lampeão, a sua fortaleza, tradição singularíssima que tem dado ao romanceiro nordestino alguns dos seus romances mais notáveis como riqueza de invenção". (Idem, p. 99, grifos meus).

Termina sua leitura do folheto, comentando:

Este é o mais bonito dos romances de Lampeão e certamente um ótimo exemplar da literatura de cordel nordestina. Sem abandonar a verdade histórica, é admirável a destreza com que o cantador se transporta da verdade pro lendário, fundindo história e liberdade de invenção com uma firmeza excepcional... Quanto aos versos que estão com os pés errados pela métrica erudita, convém notar que a dicção cantada os reduz sempre ao metro certo, pois são obras feitas pra serem cantadas e não lidas. E além disso muita conjunção dando oito sílabas ao verso (“(E) marcando-lhe o pé na goela” por exemplo) na verdade não existe no canto. Surge por atrapalhação gramatical do poeta quando, em vez de cantar desprendidamente, ele dita pra cópia ou, mais raramente escreve os versos que inventou. (Idem, p. 94, grifos meus).

Os trechos selecionados permitem-nos observar que Mário de Andrade não estabelece distinção entre artistas de extrações sociais diferentes, ambos capazes de fazer obra de arte. Não estabelece distinções que, décadas depois, tornaram-se quase um clichê (pernóstico, por sinal): a arte difere do artesanato. Para Mário de Andrade artesanato é modo de fazer entre outros recursos: "o artesanato, os segredos, os caprichos, as exigências do material, isto é assunto ensinável, e de ensinamento por muitas partes dogmático utilizados, uma aprendida na escola, outra não". A diferença, entre o artista popular e o outro, estaria no fato de que um aprendeu na escola, outro não.

No segundo ensaio, temos um resultado das leituras e utilização de sua coleção. Mário de Andrade faz uma distinção entre Desafio (que equivale ao improviso ou repentismo, como preferem, hoje, alguns autores) e Romance (que abrange os poemas narrativos 
considerados hoje, e já naquela época, quando publica na Revista Nova, em 1932, literatura de cordel). $\mathrm{O}$ artista não está categorizado como repentista ou escritor de folhetos. Todos aparecem como cantadores, porque a poesia popular nordestina é para ser cantada e ser ouvida por outros, como também destacou ALMEIDA, décadas depois ao escrever sobre esta tradição da literatura de cordel. Evidencia que, nos folhetos, os versos considerados "desmetrificados" por escrito, se ajustam, quando cantados. Os poemas narrativos, "que contam histórias" são publicados em folhetos. O cantador caracterizado como rural, é quem decora estes folhetos, com ajuda de quem lê, aprende e canta em qualquer lugar.

Passa a se referir a um dos folhetos de sua coleção, História do Capitão Lampeão, detendo-se em duas narrativas. Filia a primeira ao mito de Orfeu, pois o poema narra o encontro de Lampião com o Diabo. A segunda história contada em verso, que o encanta, é o Marco de Lampião. Desta destaca "a destreza com que o cantador se transporta da verdade pro lendário, fundindo história e liberdade de invenção com uma firmeza excepcional". De fato, o marco é um dos gêneros que existiu nas três primeiras décadas da existência do folheto de cordel. Um poeta escrevia e publicava um marco. Outro poeta, em seguida, publicava um outro marco para "derrubar" o anterior e outro mais... instaurando-se, desse modo, um desafio entre poetas através de vários folhetos, que continham os marcos. Mário de Andrade tinha alguns em sua coleção. O mais longo deles, $O$ marco paraybano, de autoria de José Adão Filho, foi escrito em 5 fascículos, cada qual um folheto. Mário de Andrade possuia três deles: o 1, o 3 e o 4. Os fascículos foram publicados em 1921, pela Typografia Chaves, de Recife, com a observação na capa de cada um deles: "Obra para ser cantada ao som da viola, desafiando qualquer outro 'Marco' publicado até hoje conhecido em todo Brazil”.

O folheto analisado por Mário de Andrade, História do Capitão Lampeão tem 42 páginas sendo assim numeradas:

1) História do Cangaceiro Lampeão, com o subtítulo: A lucta no Serrote Preto, $O$ Feixamento do corpo de Lampeão por um Feiticeiro, O pacto de Lampeão com o Diabo e A lucta com uma tigre - o primeiro poema apresenta-se com páginas numeradas de 1 a 30 ;

2) Os decretos de Lampeão, com o subtítulo: Como ele foi cercado em "Tenório" e a morte de aseu irmão Levino Ferreira - numerado de 1 a 6;

3) O Marco de Lampeão numerado de 1 a 4, seguida de uma lista de edições em duas páginas, em que é retomada a numeração, pois na última página desta lista aparece o número 32 , referente à página 32.

4) Deste modo foram inseridas neste volume uma numeração de 32 páginas, mais dez páginas, o que resulta em um a brochura de 42 páginas, o total desta edição de folheto.

No verso da capa estão impressos o título, "Como Lampeão tomou pacto com o Diabo dando-lhe o sangue de suas veias" seguido de uma ilustração em clichê. No verso da quarta capa é anunciado o folheto: História completa de Lampeão, contendo A lucta no Serrote Preto, O Fechamento do corpo de Lampeão por um feiticeiro, O pacto de Lampeão com o Diabo e A lucta com uma tigre. Em seguida, os dados da Editora; F. C. Baptista Irmão, Popular Editora, Parahyba, 1-5-1925.

Como ocorria com os livros de sua biblioteca, sempre que possível, adquiria dois exemplares, um deles ganharia anotações à margem do texto. Manuseando os folhetos de sua coleção, veremos que alguns estão anotados. Essas histórias sobre Lampião a que se referiu no ensaio, contêm os traços a lápis preto e de cor vermelha e alguns comentários manuscritos. Dá para perceber como Mário de Andrade se envolvia com as histórias durante a leitura e como estes livros eram seu material de trabalho. É pena não haver espaço para apresentar 
várias capas destes folhetos da coleção de Mário de Andrade. Seguem algumas anotações que fiz sobre o total dos folhetos escaneados que compõem a coleção "Cordéis de Mário de Andrade", cuja cópia em CD recebi em doação do IEB, feita em dezembro de 2007.

São noventa e sete pastas contendo cada qual um exemplar impresso de publicações populares, a maioria delas "folhetos", "livros de versos", "livrinhos" "versos", como aparecem denominadas essas histórias versadas pelas imprensas populares nordestinas, reconhecidas hoje como literatura de cordel, com exceção de alguns pesquisadores, poetas, editores e público tradicional que a conheceram com as antigas denominações e até hoje relutam em aceitar a denominação que se tornou hegemônica. Além da literatura popular nordestina, esta coleção contém vários exemplos daquilo que Charter classifica como "fórmula editorial", publicadas em outros estados brasileiros e em outros países. O que chama a atenção nesta coleção, já à primeira vista, é a semelhança gráfica dos impressos de produção variada, ao gosto popular. Tem-se cancioneiro peruano, mistura de prosa com poemas (em que se contam os milagres de uma santa mineira), letras de canções de Noel Rosa e outros, coletâneas de letras de músicas de carnaval, publicadas não só por prelos populares.

Há dois exemplares de uma edição da Livraria Garnier, de Paris. Trata-se do folheto Conversação de Pai Manoel com Pai José na Estação de Cascadura sobre A Questão AngloBrasileira e a Guerra do Paraguay. Rio de Janeiro; Paris: H. Garnier, 16 p. (Biblioteca Popular). No verso da capa há os títulos da Biblioteca Popular. A folha de rosto dá indicações dos livreiros do Rio de Janeiro e de Paris. Na última página há informação sobre impressão: Imp. Ferdinand Imbert, 7, Rue des Canettes, Paris. A linguagem empregada representa a fala de negros. Estrofes de dez versos, totalmente diferente do que se faz no Nordeste. É um dos exemplos de "fórmula editorial" desta coleção. Outro exemplo interessante é um folheto publicado em Curitiba, em que se mesclam versos em português e em alemão. O que dá unidade à coleção: os textos serem publicados entre os anos 1900 e 1940. No que se refere ao nordeste, a variedade de gêneros que compõem esta literatura popular em versos para ser lida e cantada é significativa. A quantidade dos chamados folhetos de época que fazem a leitura de diferentes fatos sociais e históricos, fazem sobressair a representação das disputas políticas em vários estados, o cangaço, a seca, a carestia, tratados com humor e crítica.

Outro aspecto a salientar: aí estão muitos títulos que se transformaram em clássicos desta literatura, reproduzidos em diferentes edições ao longo do século XX e também no início deste. No que se refere às letras de sambas, aí também constam os que se tornaram referência, como os sambas de Noel, por exemplo. Na atual fase de estudo e consulta a esta coleção, estou procurando marcas do autor ou editor dos folhetos nordestinos, dirigindo-se ao leitor, que me deem uma pista de quem era esse leitor, o que ele gostava de ler. Outro aspecto de meu estudo em desenvolvimento: comparar as ilustrações das capas dos folhetos com as matrizes existentes na Lira Nordestina, Crato, CE. Já encontrei várias ilustrações que indicam ser remanescentes das editoras de Leandro Gomes de Barros e de João Martins de Athayde. Todos os títulos de ambos editores, após a morte de João Martins de Athayde, foram vendidos para José Bernardo da Silva, que com suas filhas e netos como proprietários se mantiveram por muitos anos, até que o acervo da Lira Nordestina foi vendido para a Universidade Regional do Cariri - URCA. A respeito recomendo a leitura da tese de Rosangela Vieira Freire (ver na Bibliografia final).

Voltando à coleção de cordéis de Mário de Andrade. As publicações datadas de 1910 a 1935, são fontes fundamentais para caracterizar este sistema em processo.

Os poemas narrativos, impressos ou veiculados oralmente, como veremos a seguir, versavam acontecimentos, presenciados diretamente por escritores e público (tragédias e flagelos que atingiam um grande número de pessoas); narravam façanhas extraordinárias de bois e vaqueiros, associadas pelos leitores/ouvintes com ocorrências cotidianas ou com narrativas imaginárias; histórias de cangaceiros, valentões, fazendeiros, beatos, enfim, um 
conjunto de personagens que lembravam pessoas existentes na realidade, muitas vezes mescladas com muita criatividade, como as histórias de Lampeão mencionadas nos ensaios de Mário de Andrade. Parece que nem tudo foi mantido na memória dos leitores que formaram o seu gosto pelo folheto através da memória, que retinha as narrativas versadas, sobretudo, pela mediação da voz, dizendo os versos ou cantando. Esta memória do corpo que fala alto, como demonstram os colaboradores de ALMEIDA, de CAVIGNAC e tantos outros com os quais temos a sorte de conviver ainda hoje.

No que se refere à parte material destas publicações recorro a Ruth Terra, que nos dá a informação:

Nos folhetos publicados até os anos 20 predominam as capas com vinhetas. As xilogravuras, utilizadas a partir dos anos 30, concorriam com as capas ilustradas com clichês de cartões postais ou fotos de artistas de cinema, apenas nos últimos anos aparecem em maior número de capas. Pesquisa realizada em 1978 revela que as fotografias e os desenhos são preferidos às xilos. O xilógrafo Stênio Diniz relata que começou (por influência do público universitário) a trocar as capas de desenho por xilogravura. Ao substituir na reedição de um folheto o desenho de uma princesa recebeu reclamação dos revendedores que alegavam a queda na saída daquele folheto, em virtude da alteração da capa. A batalha de Oliveiros com Ferrabrás, publicada em 1909, apresentou, até 1920, capa com vinheta. Em edições posteriores, passou a ser ilustrada com clichê que reproduz um quadro de batalha. Em 1973 este folheto aparece com xilo de Stênio Diniz. Possivelmente pelo mesmo motivo apontado na pesquisa citada, encontramos edições mais recentes com o clichê antigo. O conteúdo do poema continua inalterado e as edições se sucedem desde 1909. (TERRA, 1980, p. 4).

\section{Uma literatura que já nasce madura}

A leitura das produções dos escritores de folhetos publicados nos primeiros trinta ou quarenta anos revela que são de grande qualidade literária, o que nos leva a afirmar que já nasce madura. Independente do nome (folheto, cordel), o fato predominante é que, com essa literatura popular em verso, foi trazido para o espaço da cultura com escrita não só o gosto tradicional popular, mas o que era experiência vivenciada, não só como poesia pela rede de pessoas que integram esse sistema literário em processo. Muitos dos acontecimentos estavam ocorrendo na região ou viraram notícia do que acontecia no mundo e chegavam ao Brasil. Também não estavam distantes do público os autores e editores. O público leitor, no caso do público tradicional, estabelecia um contato direto com os agentes desta rede ao comprar os folhetos nas bancas de venda, tendo, muitas vezes, o autor como vendedor e revendedor.

A literatura de folhetos, apesar de se apresentar como cultura escrita, contém, vale lembrar mais uma vez, muitas marcas da oralidade, como a rima, a métrica (em redondilha maior, com os versos de sete sílabas), a oração (a articulação dos versos de uma estrofe que fluem como na fala), o ritmo dos versos reforçado muitas vezes por melodias que acompanhavam a leitura cantada, as estruturas formulares, tudo isso a auxiliar a memorização e facilita a maior duração das histórias na memória do ouvinte/leitor.

Sabe-se que a memorização confere aos textos uma duração maior e diferentes temporalidades. O público tradicional dos folhetos, tanto pode fazer a leitura individual em silêncio ou vocalizada diante de ouvintes, de modo que estes usufruam os poemas narrativos e os guardem na memória, lendo-os através dos olhos e da voz dos outros, tanto no ritmo da fala, quanto com melodia e canto. 
Quem é o público do folheto?

O público leitor, formado por adultos, jovens e crianças, também incluía iletrados, que em vez de ler, com o auxílio de amigos e parentes, ouviam atentamente, decoravam os poemas narrativos, ouvidos, conservando na memória os textos preferidos. Talvez seja o único caso no mundo de um sistema completo nas mãos das classes trabalhadoras rurais/urbanas e proletárias - do criador, editor, tipógrafo, distribuidor, leitor/ouvinte. Muitos leitores aprenderam a ler, de tanto ouvir e acompanhar a leitura declamada ou cantada, observando os sinais gráficos nas páginas dos folhetos.

Outra característica desta literatura - que precisa ser sempre lembrada - ela não se destina à leitura silenciosa, individual e sim à leitura coletiva. Sobre a leitura, acompanhemos, o estudo de Arantes (1982):

$\mathrm{Na}$ leitura de folhetos em casa, as pessoas em geral reproduzem o modo de leitura do folheteiro [...]. Nas reuniões de vizinhos ou amigos, em horas de folga, quem sabe mais canta ou declama folhetos, segurando o livrinho e repassando o texto, embora muitas vezes já o conheçam de cor, totalmente ou em parte, exatamente como acontece com o folheteiro na feira. Os ouvintes (homens, mulheres e crianças) respondem ao leitor de acordo com o que acontece no enredo, rindo e manifestando aprovação a valores expressos nos poemas, através de frases estereotipadas como: "êta cabra valente da gota!" "É valente demais, homem!". etc.

Observando essas situações, torna-se evidente que, embora esses poemas sejam escritos e circulem em forma impressa, eles se destinam a ser lidos em voz alta ou cantados. Na verdade, o próprio formato do folheto indica isso. Nas edições usuais, a única ilustração é a de capa, que vários editores e folheteiros disseram ser um dos meios pelos quais o matuto analfabeto reconhece graficamente o poema que quer comprar; às vezes, dizem eles, alguém se recusa a comprar um folheto reimpresso com capa diferente, temendo não encontrar o texto que estava procurando. (ARANTES, 1982, p. 36).

Ainda sobre o público, acompanhemos outros exemplos, de Mauro W. B. de Almeida, pesquisador de campo em suas entrevistas feitas nos anos 1960/70. Um dos entrevistados diz a Mauro:

O folheto tem essa doçura do verso. E o povo nordestino se acostumou a ler o verso. [...] (E-36 Manoel de Almeida Filho).

Então o livro em prosa mesmo ele não gosta. [...] E nem gosta do jornal, a notícia do jornal. Ele não entende. [...] Porque está acostumado a ler rimado, a ler versado. [...] Aquela notícia não é boa para ele, o folheto sim, porque o folheto ele lê cantando. (E-36) (Grifos meus).

Sobre o vendedor:

"Eu já cantava folheto, cantava como o próprio vendedor." (E-18 João Severo da Silva (Cícero)). O vendedor, folheteiro, é então modelo da leitura oral e coletiva do folheto; da encenação dramática típica do leitor competente. (Uns tempos atrás, eu mais moço, quando eu lia na feira com entusiasmo, com gosto, o matuto com um saco enrolado no braço ficava um tempão assim parado, apreciando. Se o assunto era de briga, eu lia como quem está brigando, eles gostando. Se era de sentimento, eu queria até chorar e se era de gracejo, eu lia com muito engracejo, que eu também tenho 
um pouco de comicidade. (Depoimento de João Ferreira da Silva). (ALMEIDA, 1979, p. 55, grifos meus).

Outro poeta:

Quando foi à escola pela primeira vez, com 12 anos de idade, outro poeta levou apenas quinze dias para ler folheto, que desde os sete anos já comprava para outros lerem. Com dez meses de escola "tava feito um Cancão de Fogo", o herói sabido da literatura popular, já sendo capaz de ler para os outros, conhecendo bem o assunto. (E-24 José Francisco Borges).

Esses depoimentos falam, assim, de um aprendizado de curta duração, com a finalidade de ler folhetos comprados em feira. (ALMEIDA, 1979, p. 56-57).

Mauro conclui esta parte comentando:

Isso tudo permite explicar o aparente paradoxo de difusão de livros (= folhetos) entre um público camponês em grande parte analfabeto. $\mathrm{O}$ mecanismo de leitura coletiva no âmbito da moradia é essencial para pensar esse fenômeno [...].

Esta era a situação do folheto através de pesquisas feitas entre 1960/1970. O que tenho presenciado não é muito diferente até hoje para o público tradicional do folheto.

Ruth Terra, ao tratar da "propalada crise do folheto", que ocorre na década de 60 , refere-se à Tipografia de José Bernardo da Silva em Juazeiro do Norte que atingiu grandes índices de venda nos anos 50, chegando a editar "até 12 mil folhetos por dia, passa a editar 1 a 2 mil folhetos por semana, até o novo surto de folhetos, a partir da década de 70, quando as tiragens sobem para 12 mil exemplares semanais ", conforme dados publicados em Antologia da literatura de cordel (1978), publicação cearense resultante do Projeto literatura de cordel, realizado naquele estado nordestino.

Dentre as causas apontadas para a crise (dificuldades de impressão, alto custo do papel) Ruth Terra refere-se a "dificuldades de divulgação e venda (proibição de cantar folhetos nas feiras - após março de 1964 - o barulho dos alto falantes nas feiras e mercados), causas essas apontadas por editores e poetas populares em inúmeras entrevistas feitas por ela em sua pesquisa de campo em Recife e João Pessoa em 1975, problemas também expostos em entrevistas feitas por Geraldo Sarno em 1968, a que a pesquisadora teve acesso.

É sempre importante lembrar o que é específico deste sistema literário. Interferências de fora do sistema sempre podem ocorrer quando se dá o diálogo entre autores e público com experiências diferentes. Por um lado, escritores, editores e vendedores de folheto são vítimas da censura e autocensura a que se impõem muitos deles com medo de perder tiragens ou exemplares, caso apreendidos. Por outro, há a pressão de um poder acadêmico que, pela insistência, acaba impondo sugestões, definições e até denominações alheias ao sistema literário do folheto (o termo cordel, por exemplo, passa a ser utilizado, por muitos poetas que não o aceitavam).

Considero que pelos exemplos e outras considerações apresentadas aqui são suficientes para o público atual dos "cordéis" entender que na atualidade temos dois sistemas de autor-obra-público-edição-venda. O antigo que persiste com sua dinâmica e fundamenta-se no público ouvinte/leitor e torna-se "Uma biblioteca falante e cantante" (AYALA; FREIRE, 2012) homens e mulheres-livros, carregando em seu corpo (memória, voz, canto) o repertório predileto.

Existe, a partir dos anos 1960, um público leitor (acadêmico, nacional ou internacional, de escolas de ensino fundamental, médio e universitário). Houve uma 
ressignificação total no sistema, considerando-se o autor - as obras - o público a que se destina esta literatura. Neste caso não é mais um sistema autônomo; se desvinculou do modo de narrar destes poemas e a produção, distribuição e venda deixa de ser direta e passa a ser intermediada por grandes editoras. Não satisfaz o antigo público que continua lendo o que era folheto e hoje é vendido pela editora Luzeiro como "Coleção Literatura de Cordel", quando conta com a mediação de raros folheteiros, que ainda existe no Crato e em Juazeiro, CE.

A este público tradicional dos folhetos nordestinos, tenho me dedicado, junto com Rosangela Vieira Freire.

Inegável que com o crescente acesso à escola e consequente aumento de escolaridade da população, surge um novo mercado para o cordel: crianças, jovens e adultos, que conhecem esta poesia através do ensino, que a inclui entre os títulos didáticos, obrigatórios até em algumas provas de ingresso a universidade. A literatura de cordel atual passou por um processo total de ressignificação, em que mudaram os autores, os editores, os leitores, o sentido das obras, os temas, os divulgadores, os leitores, embora sejam encontrados em seu repertório alguns clássicos desta literatura popular em versos.

Há alguns anos, adquiri uma versão de um dos clássicos dessa literatura $O$ pavão misterioso, publicada como livro infantil, com belas ilustrações. Só que não é o texto original, é uma adaptação feita por um dos jovens autores de evidência. A editora também não era qualquer das costumeiras e sim uma editora comercial de peso: a Editora Cortez. Outra edição neste estilo versa uma peça de Shakespeare.

Antes, a literatura popular em verso impressa, composta por folhetos e romances configurava-se como sistema editorial inteiramente popular, independente, paralelo (ou simultâneo) ao sistema editorial dominante; autônomo, a ponto de trazer para o universo da oralidade, romances europeus e brasileiros, traduzidos para a realidade nordestina e sertaneja, como ocorre com os folhetos e romances que contam a história de Carlos Magno e os doze pares de França, a história da Escrava Isaura, de Iracema, a virgem dos lábios de mel, de Gabriela (neste últimos caso, simultaneamente à adaptação para TV).

Progressivamente vai mudando e passa a atender a diferentes faixas da cultura com escrita dominante, o público escolar, ajustando as normas dessa poesia narrativa a temas ao gosto da tradição da cultura com escrita, por exemplo.

Neste contexto, clássicos como As proezas de João Grilo, podem despertar um interesse secundário e exótico, pois a referência para o público estudantil é a adaptação televisiva e fílmica da peça de Ariano Suassuna, que se apropria desse folheto e de outros para criar seu Auto da Compadecida.

A intervenção é grande a ponto de um folheto original ser reescrito em nome do "politicamente correto", como aconteceu com A chegada de Lampião no inferno. Neste processo de ressignificação, de apropriação, de adulteração de textos ajustando o folheto aos interesses de um mercado e de finalidades didáticas, tem-se a atual literatura de cordel reduzida a fórmulas editoriais de uma indústria cultural que a transforma a um tipo de literatura destinado a uma única faixa etária, a da literatura infantil ou, pior, reduzida a livro paradidático (com ficha de leitura inclusa!). De sistema alternativo caracterizado como forma não institucional de cultura passa a uma situação dependente, obedecendo às diretrizes do ensino institucional e às leis do mercado editorial.

Com tudo isso ainda falta uma pesquisa de público aos moldes do que foi feito por Antonio Augusto Arantes e sugerido por Ruth Terra, citado acima. Faltam pesquisas dos diferentes públicos atuais - tanto o tradicional, fundamentado na oralidade, quanto o novo público escolarizado. Só a realização de pesquisas de campo que busquem conhecer os modos de leitura realizados em escolas que adotam títulos da literatura de cordel pode nos levar ao conhecimento do repertório utilizado no ensino, do gosto dos professores e professoras, dos estudantes, da proporção de novos autores e de suas obras em relação aos títulos de folhetos 
tradicionais em constante reedição. Sem isso só restam especulações, pois o fato de ser posto à venda ou de ser imposto como leitura escolar, não garante que se forme um público para esta literatura de cordel. Pode se formar um público eventual e não duradouro como o público tradicional, que traz em sua voz, em seu corpo os seus clássicos.

\section{A resistente voz do folheto}

Não tive oportunidade de conhecer trabalhos sobre a leitura em voz alta ou cantada, com exceção das referências de TERRA, ARANTES, ALMEIDA. Isto porque os estudos, em sua maioria, realizados nas décadas de 60 e 70, estavam preocupados em sistematizar as informações sobre os autores, reunir as obras em coleções, classificar em gêneros, além de entender e expor o processo literário completo, como o fazem TERRA, ARANTES e ALMEIDA, acima citados. Embora em menor número, são importantes os trabalhos existentes sobre o contexto e o processo de criação dessa produção intelectual de autodidatas nordestinos, seus autores e toda a rede responsável pela circulação dos textos nas diferentes localidades da região ou para outras nas quais foi intensa a migração nordestina até os anos 70 do século XX.

Um trabalho pioneiro sobre a memória de narrativas, muitas delas relacionadas com histórias de folheto, feito nos anos 80/90 é o de Julie Cavignac (2006).

Até hoje, em que pesem as poéticas da voz, voltadas para a performance, ainda são poucas as informações sobre a simultaneidade da forma oral (cantada ou declamada) no processo de venda da produção impressa, criando um tipo de difusão específico para atrair e atender seu público leitor/ouvinte tradicional. Quando ocorre vem desprovida de som e imagem, apenas descrita pelo pesquisador, apesar de, recentemente, serem cada vez mais acessíveis bons equipamentos sonoros e audiovisuais.

Devido a essa lacuna nos estudos da poesia narrativa nordestina impressa para ser lida em voz alta ou cantada, venho desenvolvendo, desde meados dos anos 1990, sempre que surge uma oportunidade, registros de cantos de antigos vendedores de folhetos em feiras; de poetas repentistas, que ainda guardam na memória as histórias completas e de emboladores que encaixam, no meio de improvisos, trechos de romance ou de versos tradicionais. Mais recentemente, com a colaboração de Rosangela Vieira Freire, estou tendo a oportunidade de conhecer a voz de integrantes do público tradicional, a espécie de homens e mulheres-livro ou de bibliotecas falantes e cantantes, aludida anteriormente.

Estamos procurando demonstrar que o público tradicional não se contenta em conhecer o texto; quer a voz do folheto.

Gravei uma longa entrevista com Azulão, João José dos Santos, paraibano de Sapé, que migrou para o Rio de Janeiro em 1949. Foi trabalhar na construção civil e às quintasfeiras, cantava com Palmeirinha na Rádio Tupi no programa comandado por Almirante, Onde está o poeta, que, segundo Azulão, parece que foi o primeiro programa de cantadores do Brasil. Foi um dos fundadores da Feira de São Cristóvão, chegando a vice-presidente, com Manoel Alexandre Alves, paraibano de Cabaceiras, da Paraíba. Lá,

[...] acompanhando os acontecimentos, escrevia cordel, cantava de viola e vendia nas feiras. [...] Então, fui ficando por lá minha vida foi essa! Escrever romances, acontecimentos, cantar com Palmeirinha e outros colegas que apareciam por lá... e vender meus romances nas praças do Rio de Janeiro.

A entrevista foi gravada em João Pessoa, em 2001, e é a base para o vídeo Azulão: $a$ voz do folheto, mencionado anteriormente, que editei em junho de 2007 para a Série Registros 
etnográficos - Documentários, produção do Meio do Mundo. Neste vídeo, ao contar como vendia folheto disse Azulão:

Só quem cantava era eu. A roda que se fazia era devido à cantoria, à pregação ser cantada. Romances meus, de outros colegas, folhetos, histórias de gracejos então aquilo tudo... Nunca vendi folheto parado não, como quem 'tava vendendo batata, era cantando mesmo. [...] O cantador tem uma visão mais aproximada de uma peça teatral, então ele... a cada estilo, a cada assunto tem uma toada. Se o assunto é sentimento vamos para uma toada maneira, leve... Se o assunto é agressão, uma toada agressiva, assim.

Além de Azulão, entre 2003 e 2010, gravei fragmentos do Negão do Paraná inseridos em emboladas na fronteira da Paraíba com Pernambuco, além de poemas como a Chegada de Lampião no céu em ritmo de coco, com um coco tradicional como refrão, entre estrofes, e parte de Coco Verde e Melancia, em Santa Luzia, cantados por Mané de Bia. A retomada de publicação de folhetos, com o surgimento de novos autores em vários estados, motivou-me a continuar buscando a voz dos folhetos.

Tive oportunidade de conversar com alguns frequentadores da banca de um vendedor de folheto, em Juazeiro, CE enquanto escolhia um grande conjunto de títulos para comprar; pude perceber, através de suas sugestões, que as mulheres ali presentes gostavam de romances de amor, enquanto os homens preferiam os de ação, histórias de valentão, gracejos e presepadas. Mas todos gostavam do Pavão Misterioso, Coco Verde e Melancia, A chegada de Lampião no inferno. Marcamos com um dos frequentadores da banca uma entrevista, pois ele se revelou uma espécie de biblioteca viva, tantos eram os versos que tinha de cor.

As entrevistas mais recentes gravadas no Ceará com três pessoas residentes em Juazeiro do Norte e um romeiro de Alagoas atestam que existe um público tradicional, que memorizou quando jovem os poemas narrativos de sua predileção e que os conserva na memória, expondo seu conhecimento da forma que lhe é mais prazerosa, cantando ou declamando. Devo ressaltar que ao dizerem os versos em voz alta não fazem uma impostação da voz; os versos fluem como se fosse um texto em prosa. Seu Antonio de Alagoas, o mais fluente deles, carrega na memória um grande repertório, narrando um poema atrás do outro. Começou com A chegada de Lampião no inferno, passou para a Chegada de Lampião no céu, em seguida veio a Peleja de Severino Borges com Pataiva do Norte, Daniel e Geni, romance com princesa encantada, dádiva de objeto de identificação futura, ida a reino longínquo; a primeira parte do Pavão misterioso, a primeira parte da Peleja de Cego Aderaldo e Zé Pretinho do Tucum, $O$ reino do mar sem fim. Os outros entrevistados também cantaram seu repertório. Em todos apareceu A chegada de Lampião no inferno e $O$ pavão misterioso, além de outros folhetos. A conversa com o vendedor de folhetos e outros frequentadores de sua banca deixou claro que existe um público tradicional que revela suas predileções ao estimular um comprador estranho a comprar um ou outro título e dizer porque o folheto, o romance ou o verso é bom. É preciso conhecer a apreciação do leitor tradicional e comparar o repertório eleito por ele de "folhetos, romances e histórias de gracejo" a variedade de temas preferidos (valentia, amor, acontecimentos) ou ainda, no caso de pelejas quais as preferidas. São leitores, que guardam, até hoje, essas histórias dentro de si, de cor. As associações que fazem com sua vida, as histórias dos folhetos que versaram acontecimentos na região ou em outros lugares que ficaram gravadas em suas memórias.

A literatura de folhetos nordestinos sempre esteve relacionada com a voz, desde o momento de sua formação como um dos sistemas poéticos predominantes no nordeste brasileiro, sistemas que se intercomunicam, pela temática, pela utilização de regras de composição poética (rima, métrica e oração) e pelo ritmo poético, como foi exposto acima. Embora tenha a escrita na base da criação, o folheto mantém vínculos com os sistemas que se 
alicerçam na transmissão oral, não apenas por ser oralizado, ou seja, cantado ou falado, declamado, dito em voz alta, mas por ter trazido o verso da cantoria (através dos desafios imaginários, discussões e pelejas), a embolada (dos cocos de feira) ou o aboio (no entremeio dos versos das canções de vaquejada) para dentro do sistema escrito. Também podemos pensar que a poesia oral pode ter um alicerce na escrita, através de exercícios manuscritos para dar agilidade ao rimar e desenvolver temas - e atender ao princípio mais difícil do repentismo - a oração completa.

Não é demais lembrar que a criação literária popular nordestina já existia, quando se constituíram as tipografias populares que além dos trabalhos de qualquer gráfica (convites, cartões, anúncios) se especializaram na publicação de autores regionais de poemas narrativos, aos moldes do que era cantado por repentistas da época ou circulava através de cópias manuscritas.

Se é verdade afirmar que a existência dessas tipografias viabilizou o surgimento da literatura como sistema integrado de autores, obras e público, também é verdadeira a constatação de que essa literatura conservou as marcas de oralidade nos poemas narrativos impressos, desde os primeiros momentos de sua existência, sem desprezar a visão de mundo, um conjunto de valores, de fazeres e saberes, integrados à experiência ou ao universo de expectativa dos leitores/ouvintes tradicionais.

\section{Referências}

ALMEIDA, Mauro W. B. de. Folhetos (a literatura de cordel no NE brasileiro). São Paulo: 1979, 2 v. (Dissertação de mestrado, Departamento de Ciências Sociais, FFLCH, USP).

ANTOLOGIA DA LITERATURA DE CORDEL. Coordenação Roberto Aurélio Lustosa da Costa. Fortaleza: Secretaria de Cultura, Desporto e Promoção Social do Ceará, 1978, v. 1.

ARANTES, Antônio A. O trabalho e a fala. São Paulo: Kairós; FUNCAMP, 1982.

AYALA, Maria Ignez Novais. No arranco do grito. São Paulo: Ática, 1988.

Aboio: canto de trabalho e gênero poético. In: Alexandre Pimentel; Joana Corrêa. (Org.). Na ponta do verso: poesia de improviso no Brasil. Rio de Janeiro: Associação Cultural Caburé, 2008, p. 30-43.

. Coco de embolada: mágica na palavra e no pandeiro. In: Alexandre Pimentel; Joana Corrêa. (Org.). Na ponta do verso: poesia de improviso no Brasil. Rio de Janeiro: Associação Cultural Caburé, 2008, p. 58-73.

Riqueza de pobre. Literatura e Sociedade (Departamento de Teoria Literária e Teoria Literária da USP), v. 2, p. 160-169, 1997. Disponível em:

http://www.revistas.usp.br/ls/article/view/15694/17268 Último acesso em 29 nov. 2016.

. ABC, Folheto, Romance ou Verso: a literatura impressa que se quer oral. Graphos. João Pessoa, Vol. 12, N. 2, Dez./2010, p. 52-73 - ISSN 1516-1536. Disponível em: http://periodicos.ufpb.br/index.php/graphos/article/viewFile/10908/6113 Último acesso em 29 nov. 2016. 
e AYALA, Marcos (org.). Metodologia para pesquisa em culturas populares. Crato: Edson Martins Ed., 2015. Disponível em: http://www.acervoayala.com/wpcontent/uploads/2016/06/METODOLOGIA_PARA_PESQUISA_EM_CULTURAS_POPULAR ES-AYALA_ORG.pdf Último acesso em 29 nov. 2016.

e FREIRE, Rosangela Vieira. Folhetos nordestinos: uma biblioteca falante e cantante. In: COSTA, E. S.; GRUNE EWALD, F.; FERNANDES, F. (Org.). Seminário brasileiro de poéticas orais: métodos, acervos, cartografias. 1ed. Londrina: UEL, 2012, v. 2 , p. 313-328. [Anais do II Seminário Brasileiro de Poéticas Orais: métodos, acervos, cartografias, Salvador: Universidade do Estado da Bahia, 2011, p. 313-32.-ISBN:978-85-7846-134-I]. Disponível em:

http://www.portaldepoeticasorais.com.br/site/textos/ANAIS\%202\%20Parte2.pdf Último acesso em 29 nov. 2016.

AYALA, Maria Ignez Novais; FREIRE, Rosangela Vieira. Vozes do folheto: uma prática de leitura e um caso de poética oral. Boitatá, v. 9, p. 1-23, 2010. Disponível em:

http://revistaboitata.portaldepoeticasorais.com.br/site/arquivos/revistas/1/maria\%20e\%20rosa ngela.pdf Último acesso em 29 nov. 2016.

CALASANS, José. Canudos na literatura de cordel. São Paulo: Ática, 1984.

LITERATURA POPULAR EM VERSO - ANTOLOGIA. Seleção, introdução e comentário Manoel Cavalcanti Proença, Rio de Janeiro: Casa de Ruy Barbosa, 1964, t. 1.

LITERATURA POPULAR EM VERSO - CATÁLOGO. Organização Manoel Cavalcanti Proença e Orígenes Lessa. Rio de Janeiro: Casa de Ruy Barbosa, 1961, t. 1.

CAVIGNAC, Julie. A literatura de Cordel no Nordeste do Brasil. Da história escrita ao relato oral. Natal: Editora da UFRN, 2006.

CHARTIER, Roger. A ordem dos livros. 2. ed. Brasília: Editora Universitária de Brasília, 1999.

Os desafios da escrita. São Paulo: Editora da UNESP, 2002.

COLEÇÃO “CORDÉIS DE MÁRIO DE ANDRADE”. Instituto de Estudos Brasileiros, universidade de São Paulo (IEB/USP) [folhetos digitalizados].

CUNHA, Euclides. Caderneta de campo. Introdução, notas e comentários Olímpio de Souza Andrade. São Paulo; Cultrix, 1975.

. Os sertões. Ed. crítica Walnice Nogueira Galvão. São Paulo: Brasiliense, 1985. 
FREIRE, Rosangela Vieira. Tipografia São Francisco/ Lira Nordestina: práticas culturais, discurso e memória. 2012. Tese (Doutorado em Programa de Pós-Graduação em Linguística) - Universidade Federal da Paraíba.

VIANA, Arievaldo. O pavão misterioso: recriação da obra de José Camelo Resende e João Melquíades Ferreira. Ilustrações Jô Oliveira. Fortaleza: IMEPH, 2007. (Literatura de Cordel Ilustrada)

. O Cantor da Borborema e o Pavão Mysterioso (2001), Em: - A maior polêmica do cordel. Disponível em: http://acordacordel.blogspot.com.br/2012/02/maior-polemica-doordel.html. Último acesso em 30 nov. 2016.

TERRA, Ruth Brito Lemos. "Literatura de folhetos: persistência de uma forma de comunicação popular". Texto-base para comunicação apresentada no IX Encontro Brasileiro de Comunicação Social, item IV por uma memória da documentação popular, Painel "Usos e abusos da literatura de cordel". (mimeo.)

Gobal, 1983.

. Memória de lutas: literatura de folhetos do Nordeste (1893-1930). São Paulo:

DVDs

AYALA, Ignez. Azulão: a voz do folheto. (2007).

CABRAL, Elisa Maria. Olhos da alma, cantos do coração. (1999).

CALDAS, Laurita. J. Borges. (2003).

Recebido em: novembro de 2016.

Aprovado em: dezembro de 2016. 


\section{ILUSTRAÇÕES - COLEÇÃO CORDÉIS DE MÁRIO DE ANDRADE (IEB-USP) E CLICHÊS DO ACERVO LIRA NORDESTINA}

Figuras 1, 2 e 3 - Reprodução da capa e páginas interna do folheto A verdade nua e crua. A dor de barriga de um noivo. Autor: Leandro Gomes de Barros. Recife, Typographia do Jornal do Recife, 1913. 16 p (Coleção Mario de Andrade)

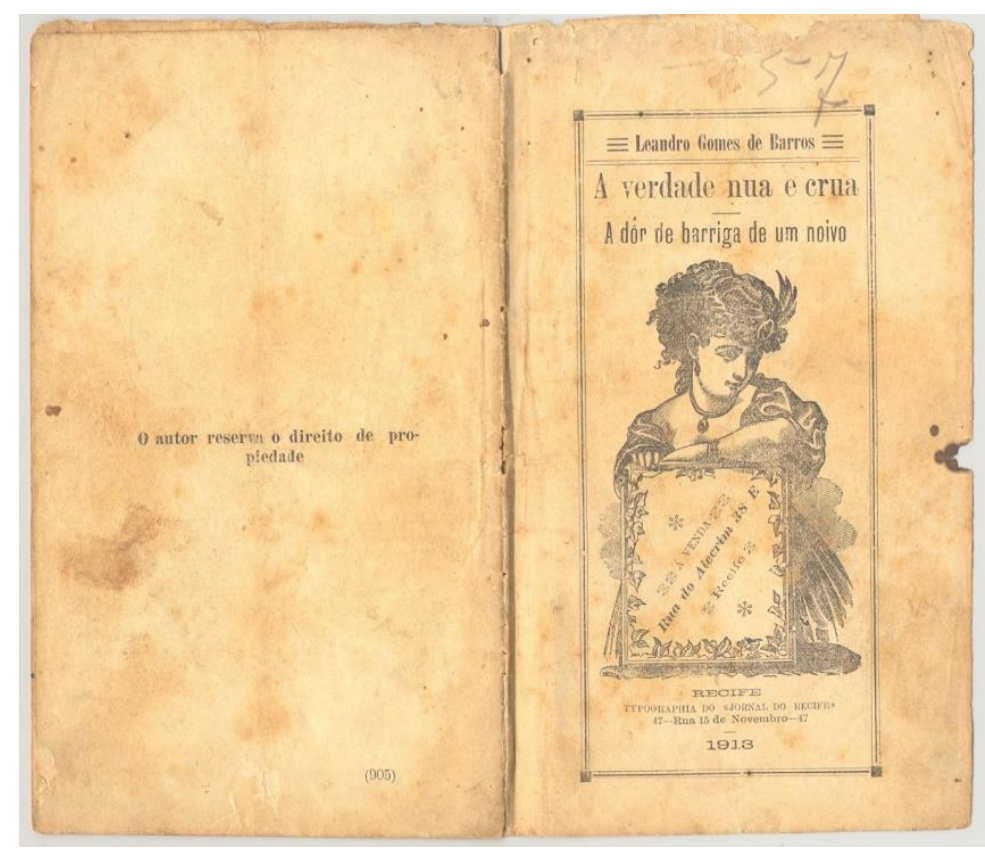

Figura 1

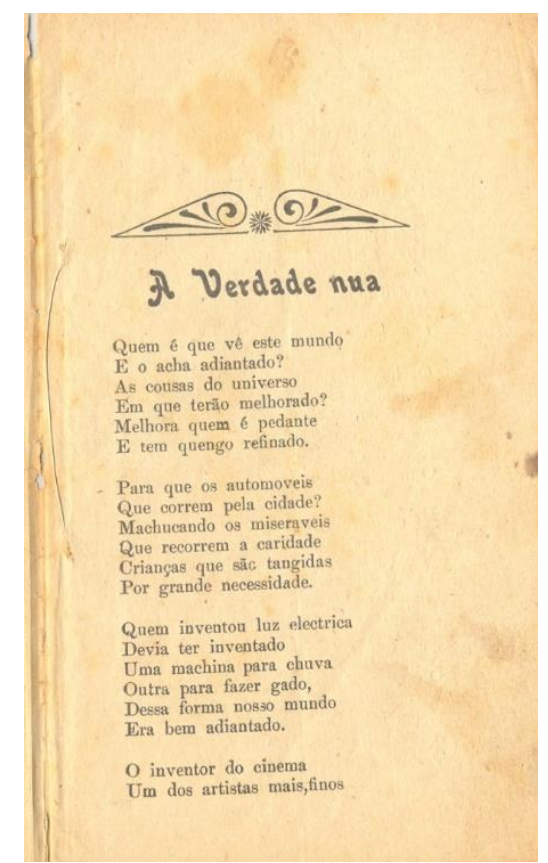

Figura 2

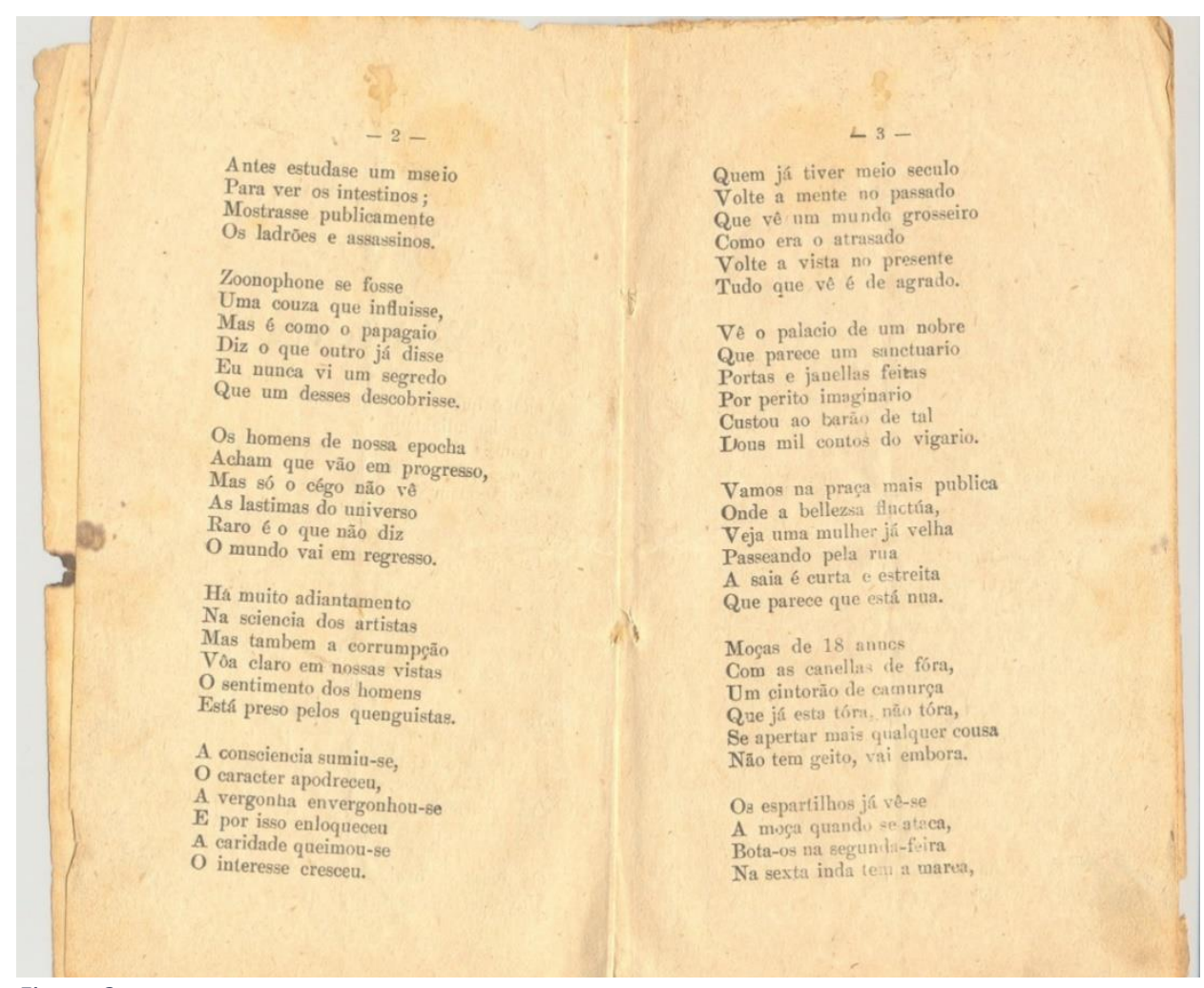

Figura 3 
Figuras 4, 5, 6 e 7 - O novíssimo ABC de Virgolino Ferreira da Silva mais conhecido pelo seu nome de guerra Lampeão! (Col. Mario de Andrade)

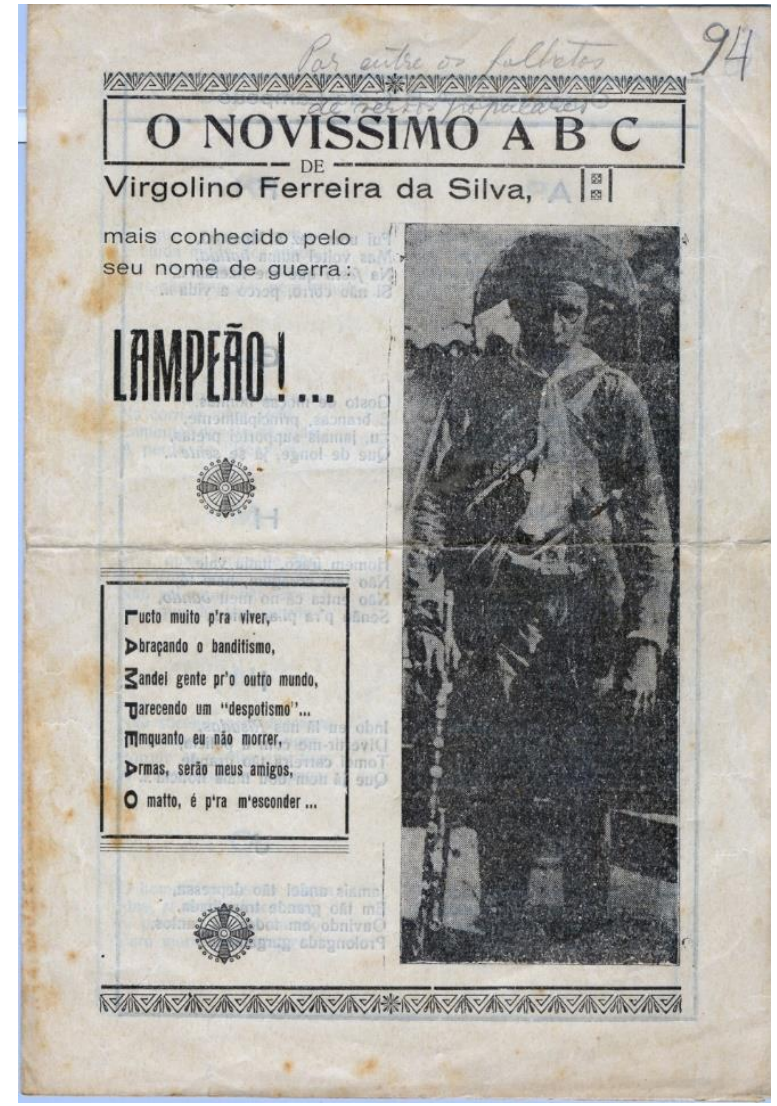

Figura 4

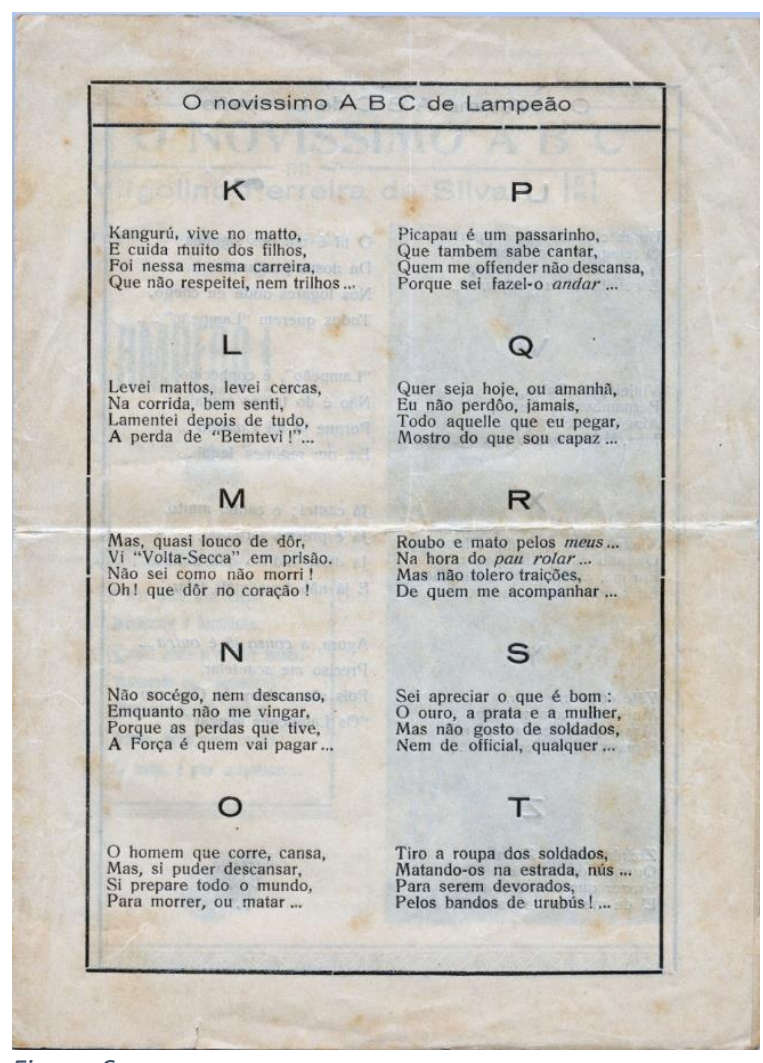

Figura 6

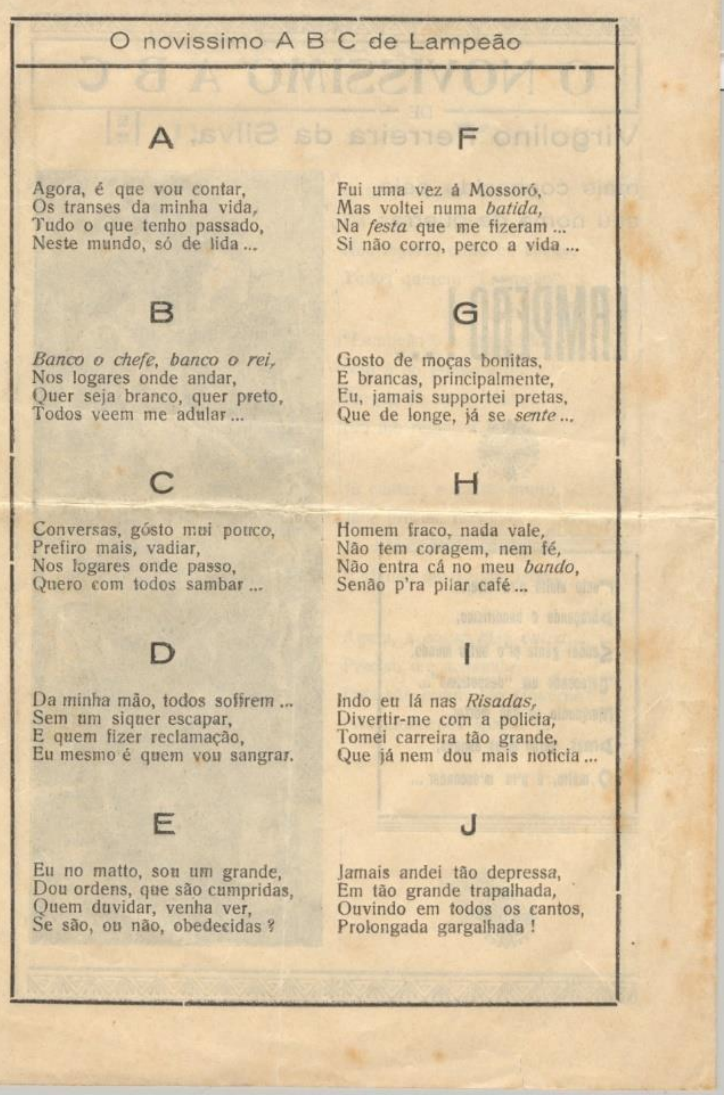

Figura 5

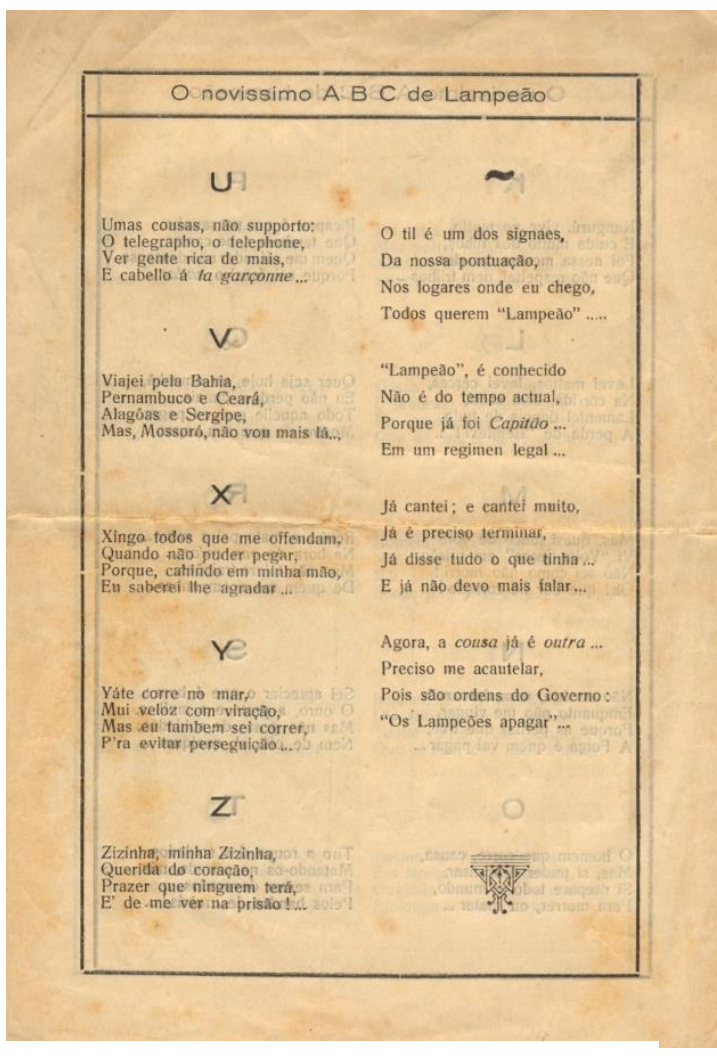

Figura 7 
Figuras 8, 9, 10, 11, 12 e 13 - A história do Capitão Lampeão desde o seu primeiro crime até sua ida a Joazeiro. Editor-Proprietário F. C. Baptista Irmão. Typ. da Popular Editora. Rua da República 584 - Parahyba (Col. Mario de Andrade)

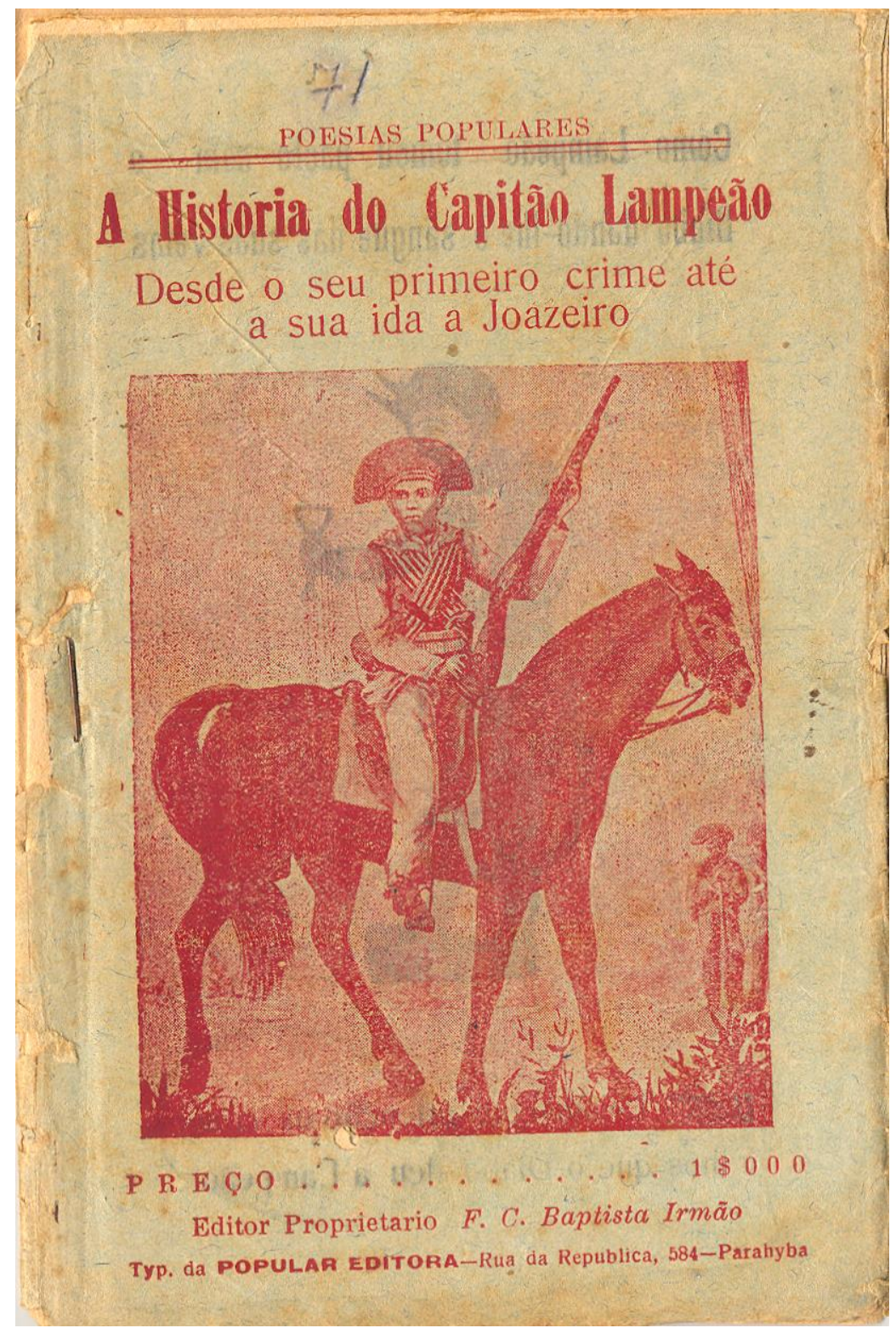

Figura 8 


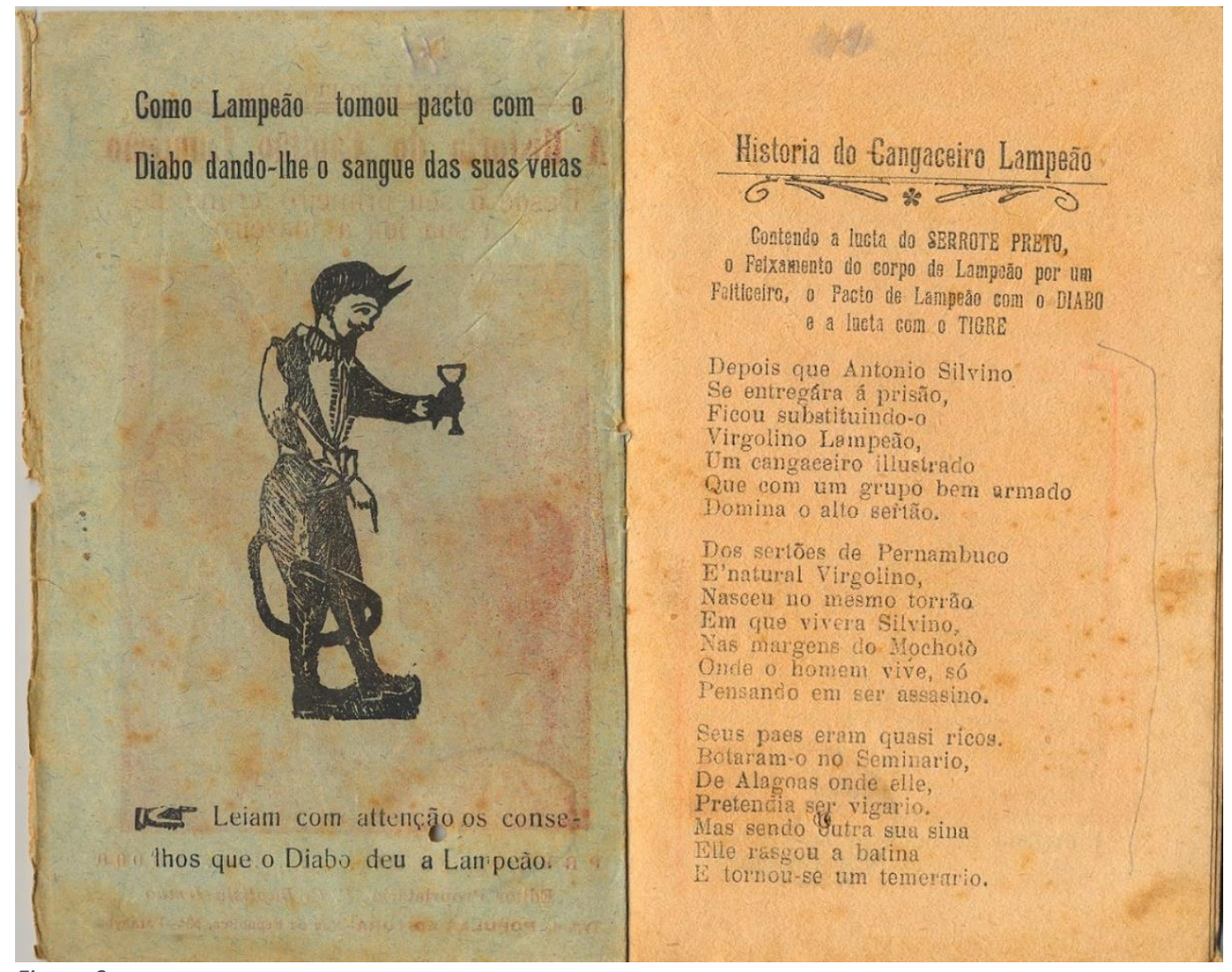

Figura 9

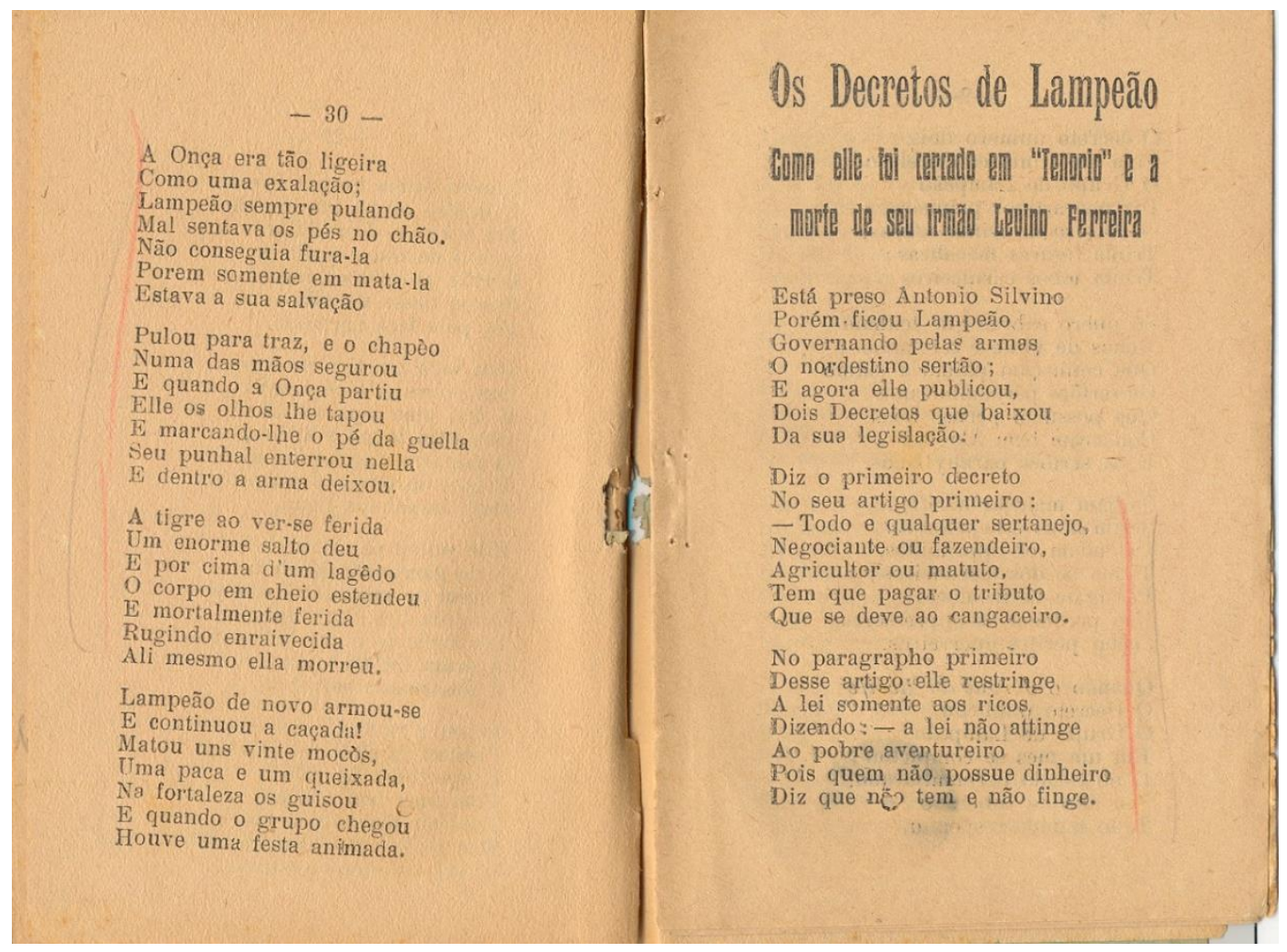

Figura 10 

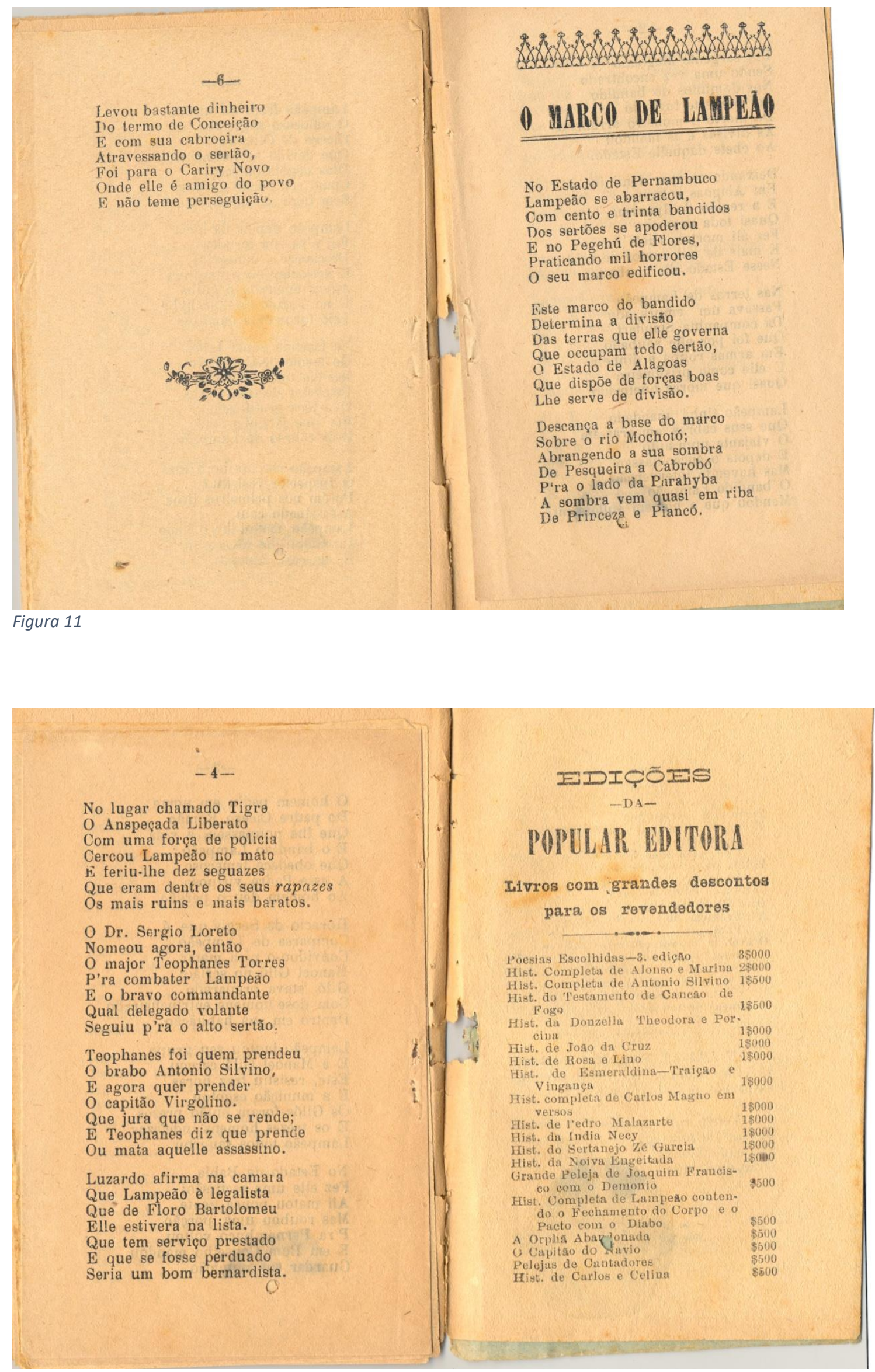

Figura 12 


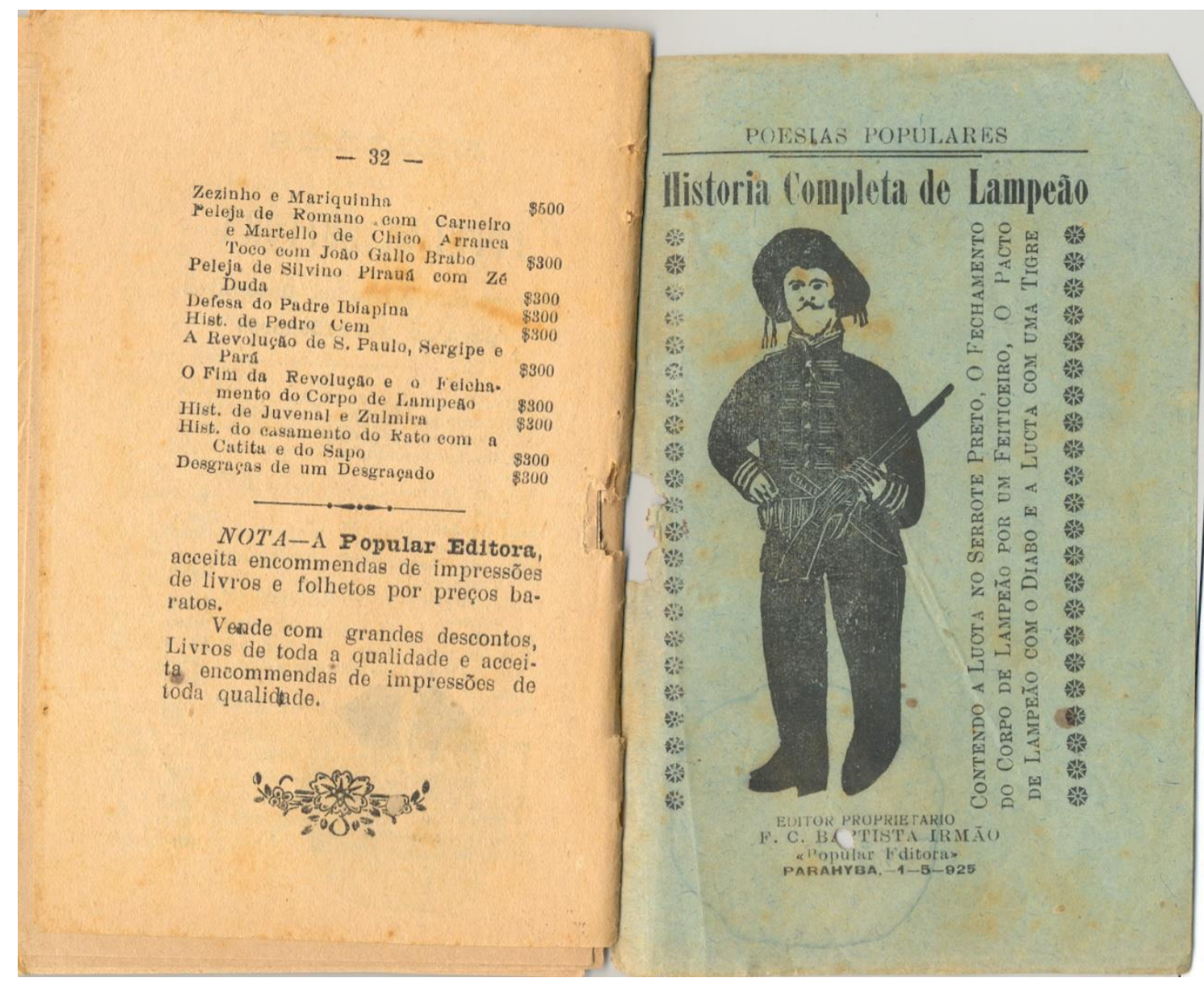

Figura 13 
Figuras 14 e 15 - A vida de Cancão de Fogo e seu testamento. Autor: Leandro Gomes de Barros. Editor: João Martins de Athayde. Recife, Pernambuco, 64 p. (Col. Mario de Andrade)

Observe na p. 64 a informação de que João Martins de Athayde se tornou proprietário da obra de Leandro Gomes de Barros.

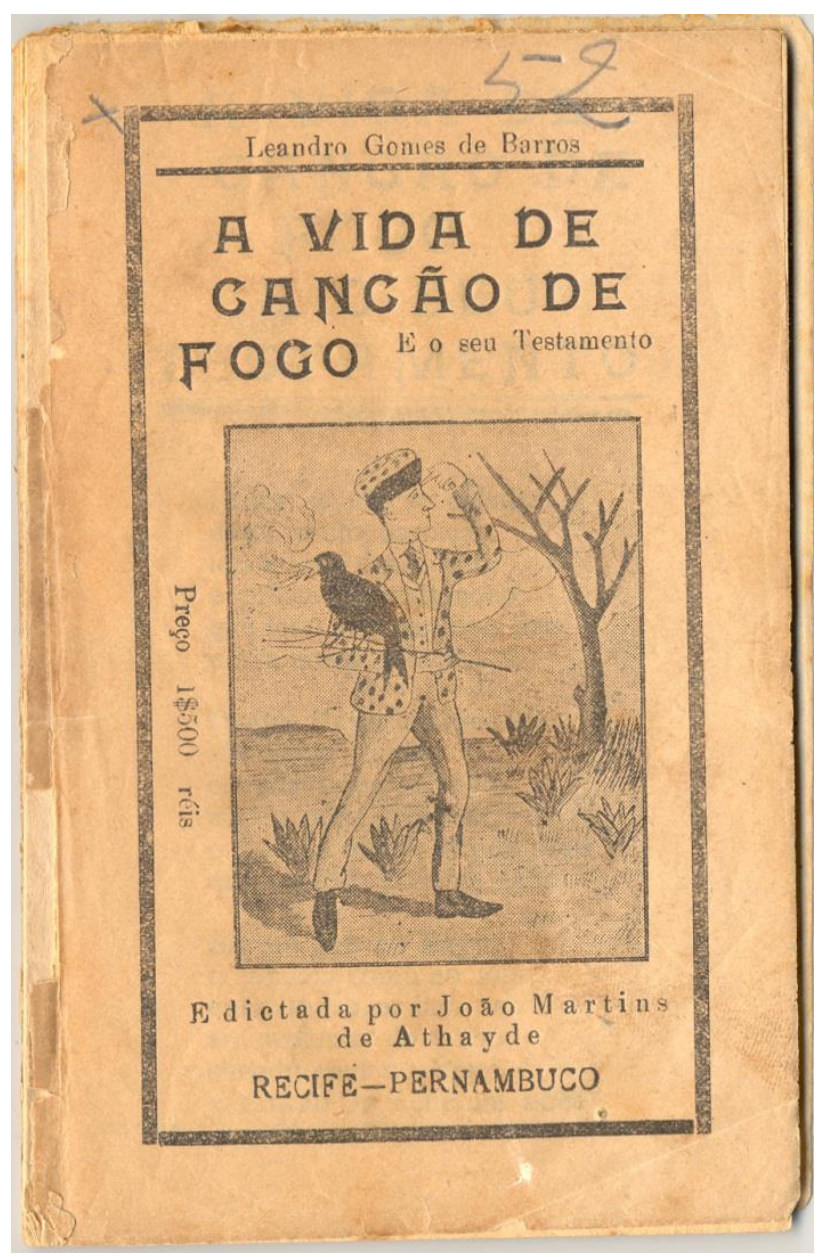

Figura 14

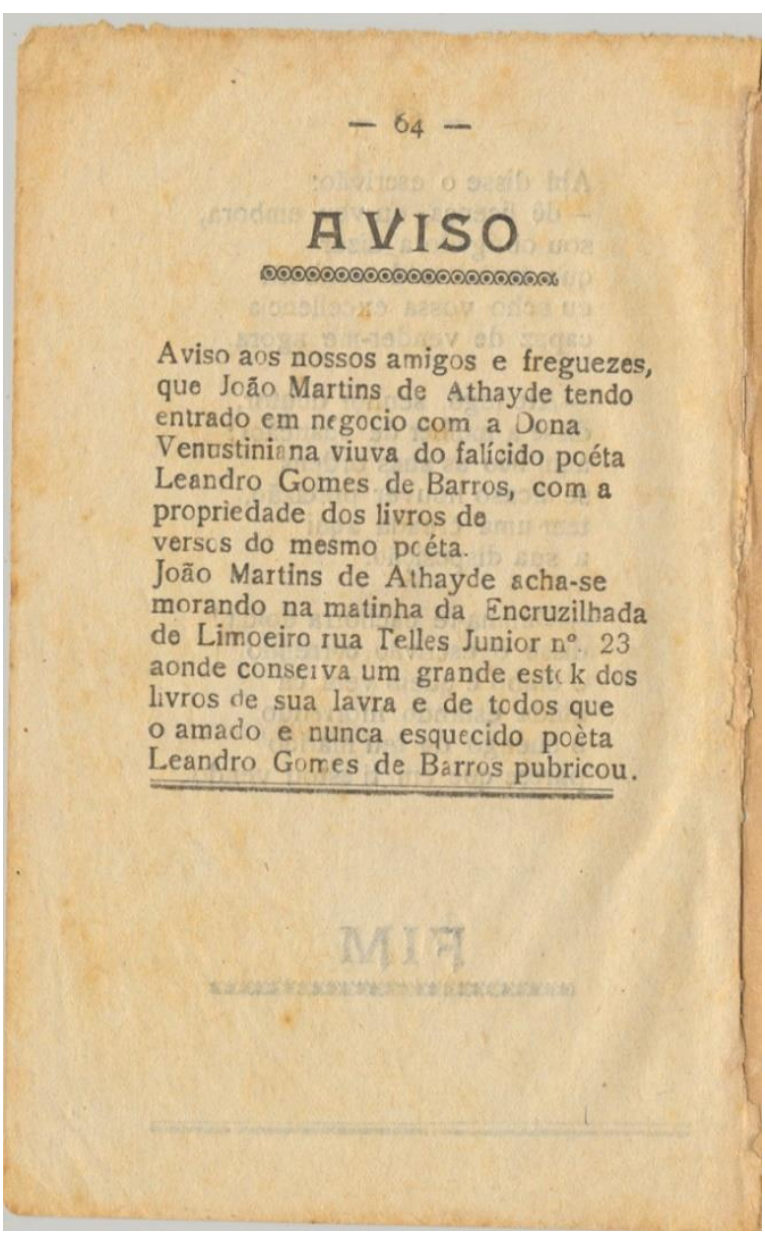

Figura 15 
Figuras 16 e 17 - Clichês do Acervo da Lira Nordestina

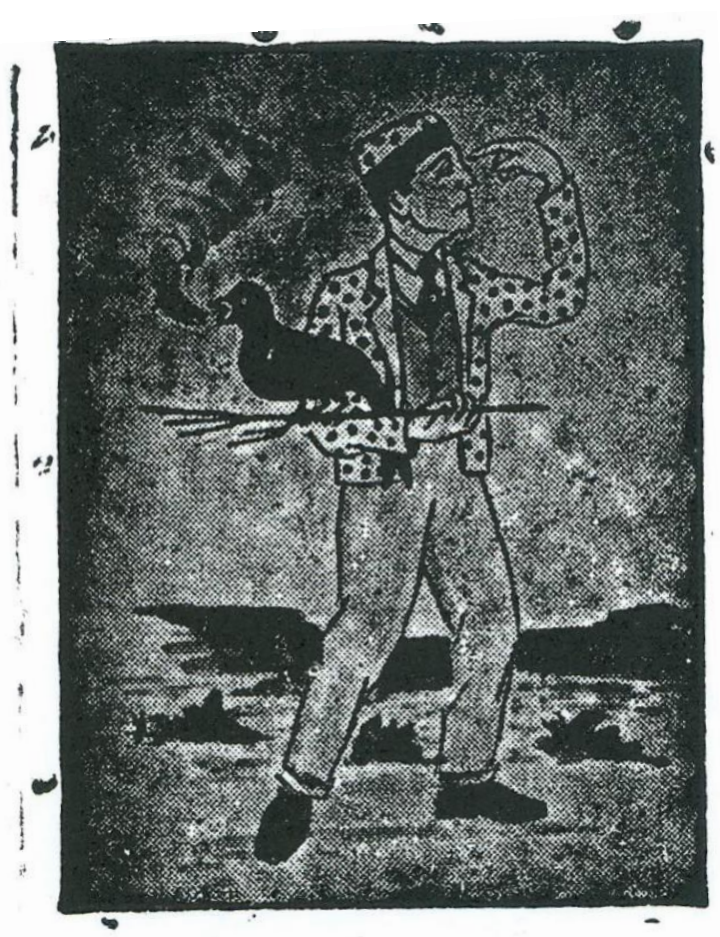

Figura 16

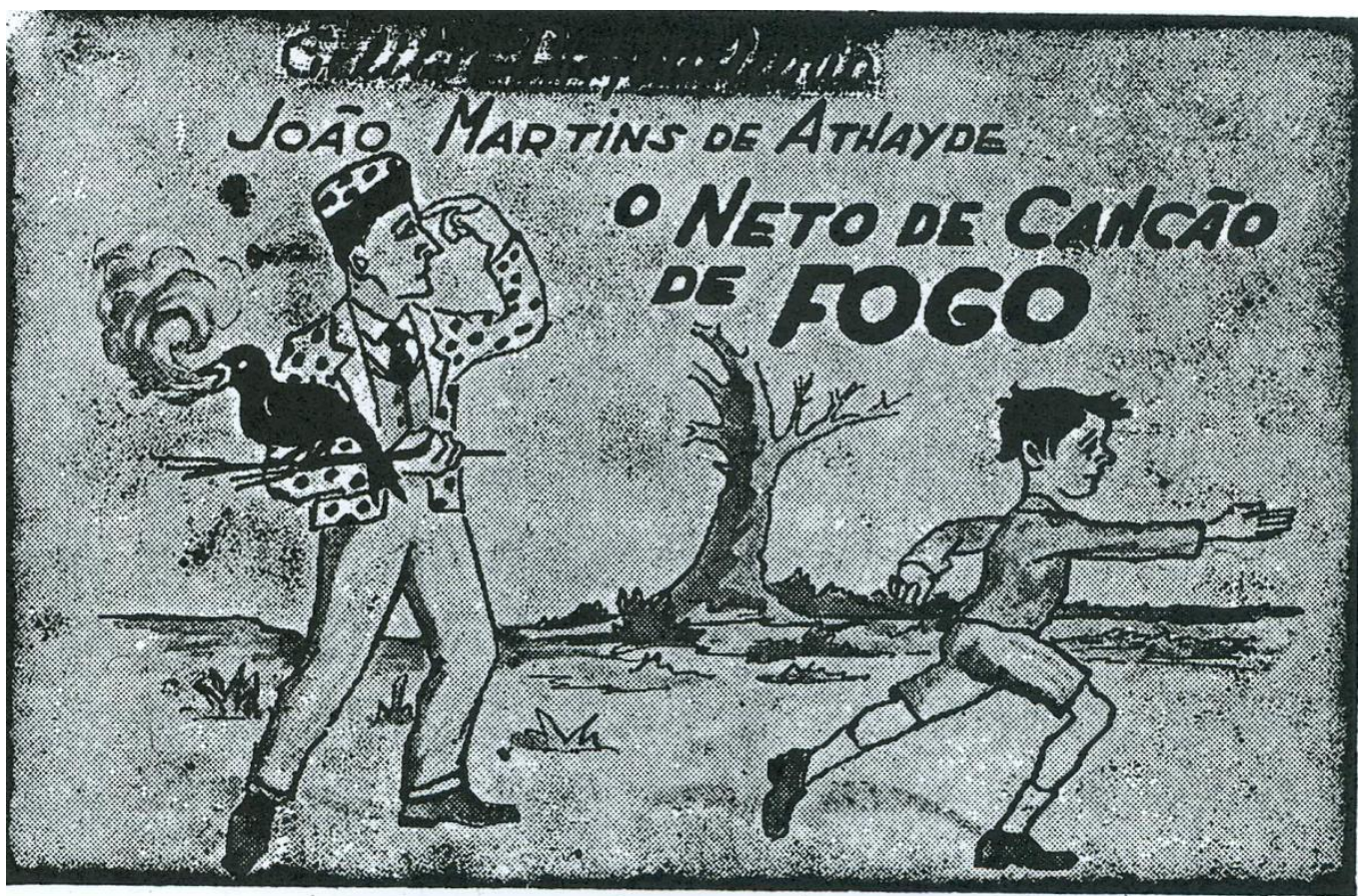

Figura 17 
Figuras 18 e 19 - A vida de Pedro Cem. Completa. Autor: João Martins de Athayde. Recife. 16 p. Col. Mario de Andrade Clichê Acervo Lira Nordestina

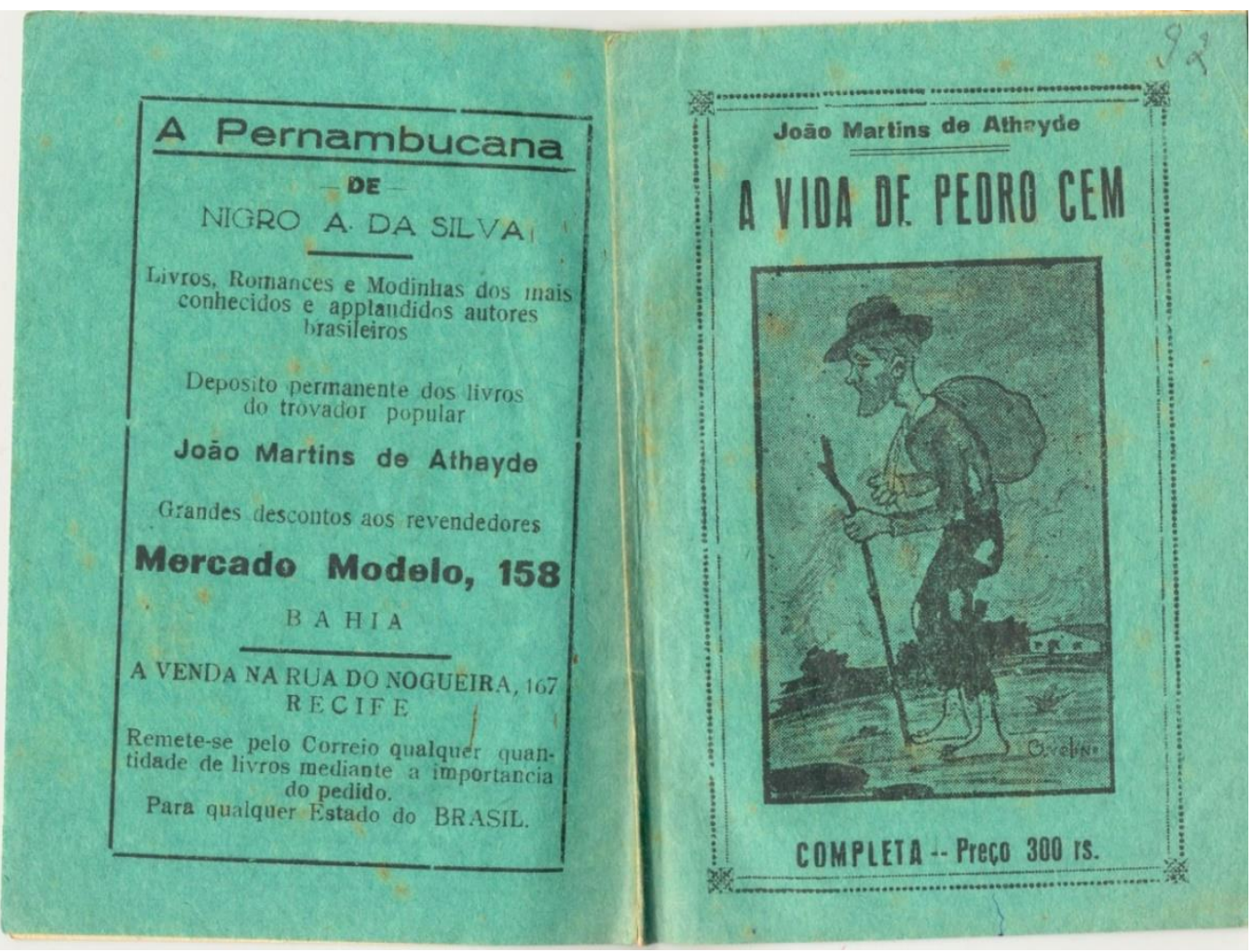

Figura 18

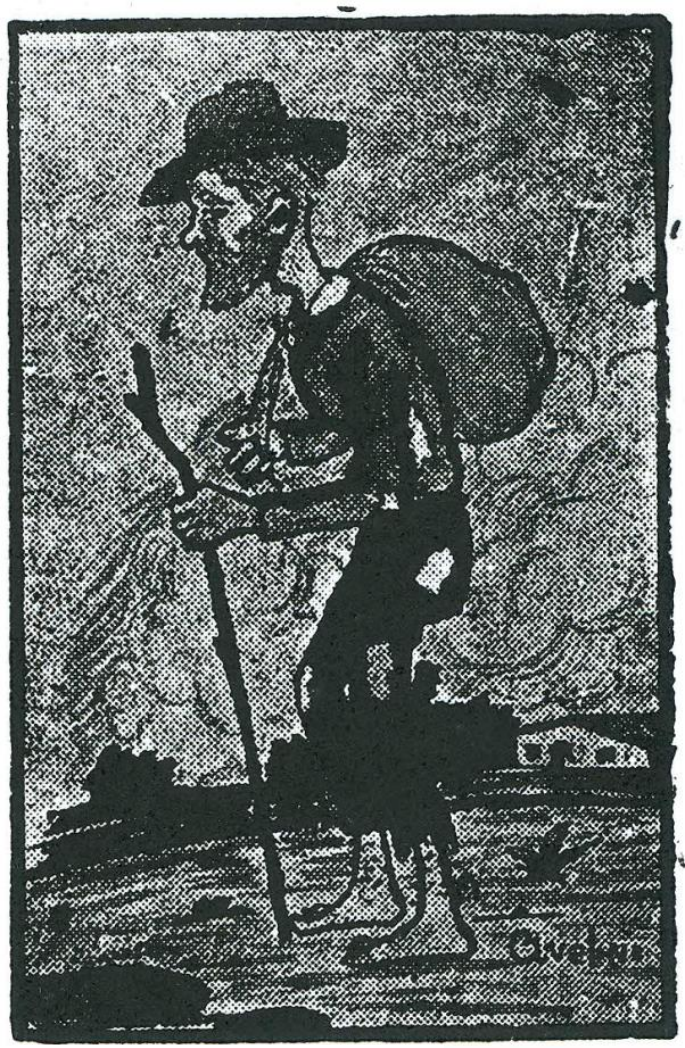

Figura 19 
Exemplos de fórmula editorial (Col. Mario de Andrade)

Figura 20 - Exemplar de uma edição da Livraria Garnier, de Paris, do folheto Conversação de Pai Manoel com Pai José na Estação de Cascadura sobre A Questão Anglo-Brasileira e a Guerra do Paraguay. Rio de Janeiro; Paris: H. Garnier, 16 p. (Biblioteca Popular).

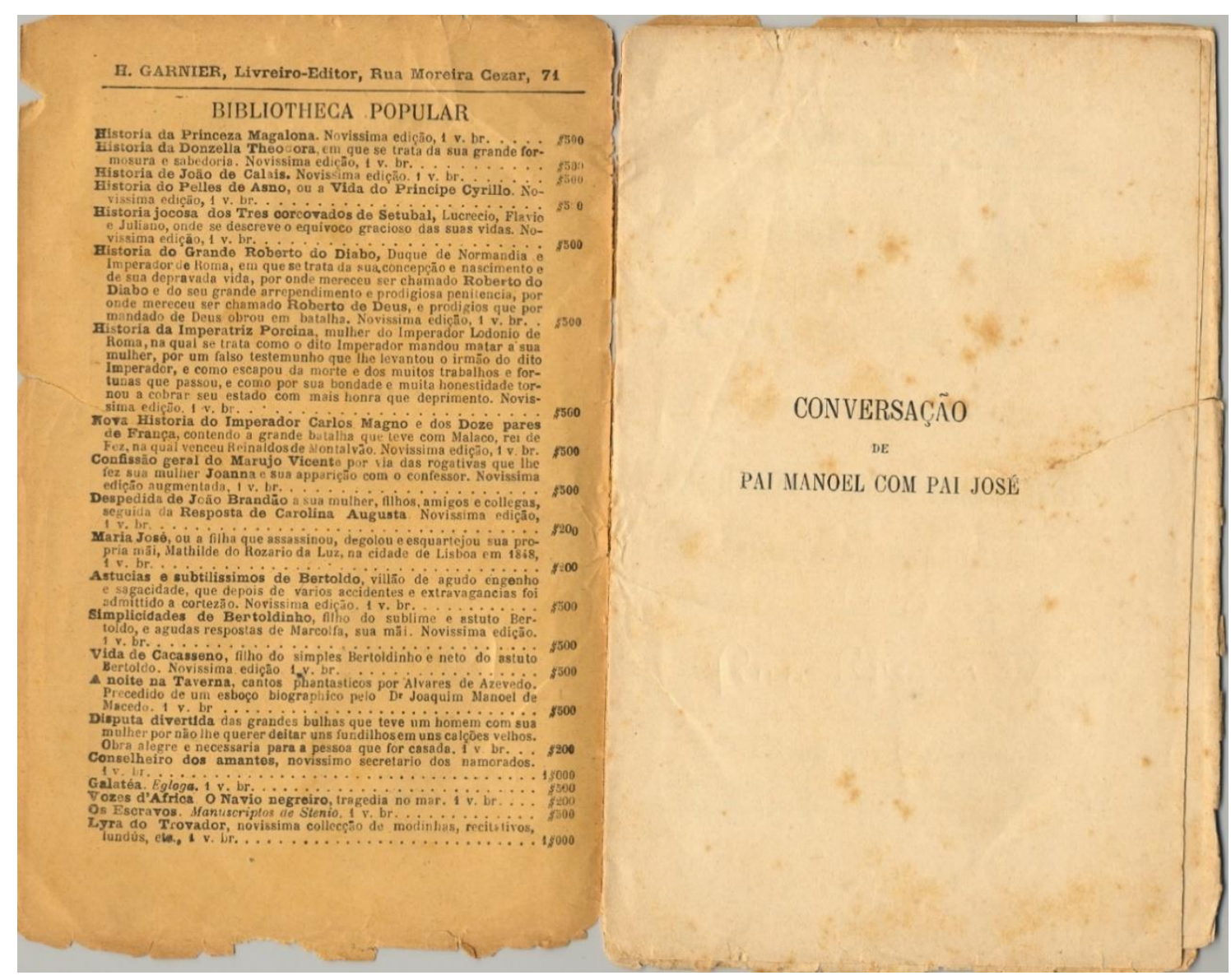

Figura 20 
Figura 21 - Verso da capa, com os títulos da Biblioteca Popular.

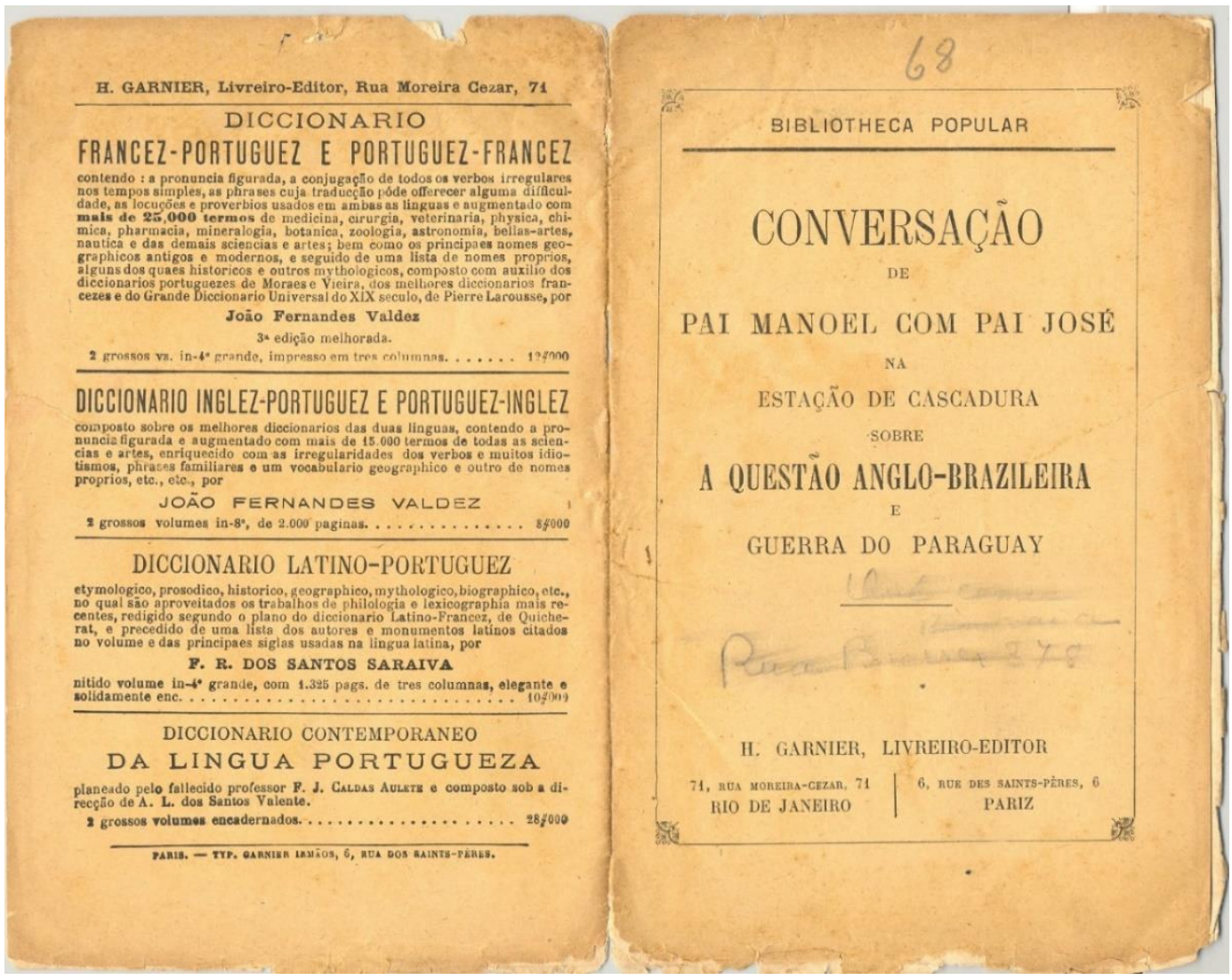

Figura 21 
Figura 22 - A folha de rosto dá indicações dos livreiros do Rio de Janeiro e de Paris.

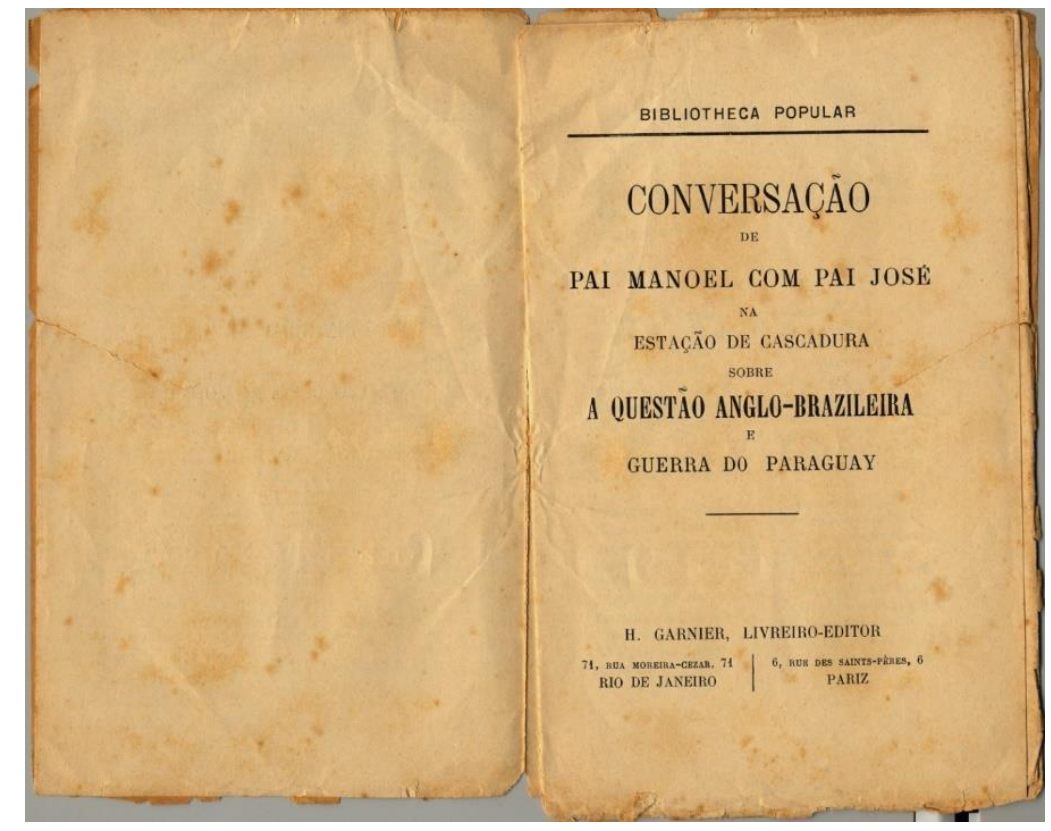

Figura 22

Figuras 23, 24 e 25 - Exemplo de fórmula editorial (Col. Mario de Andrade) Reprodução da capa, última página e páginas 1 e 2 do folheto escrito em português e alemão.

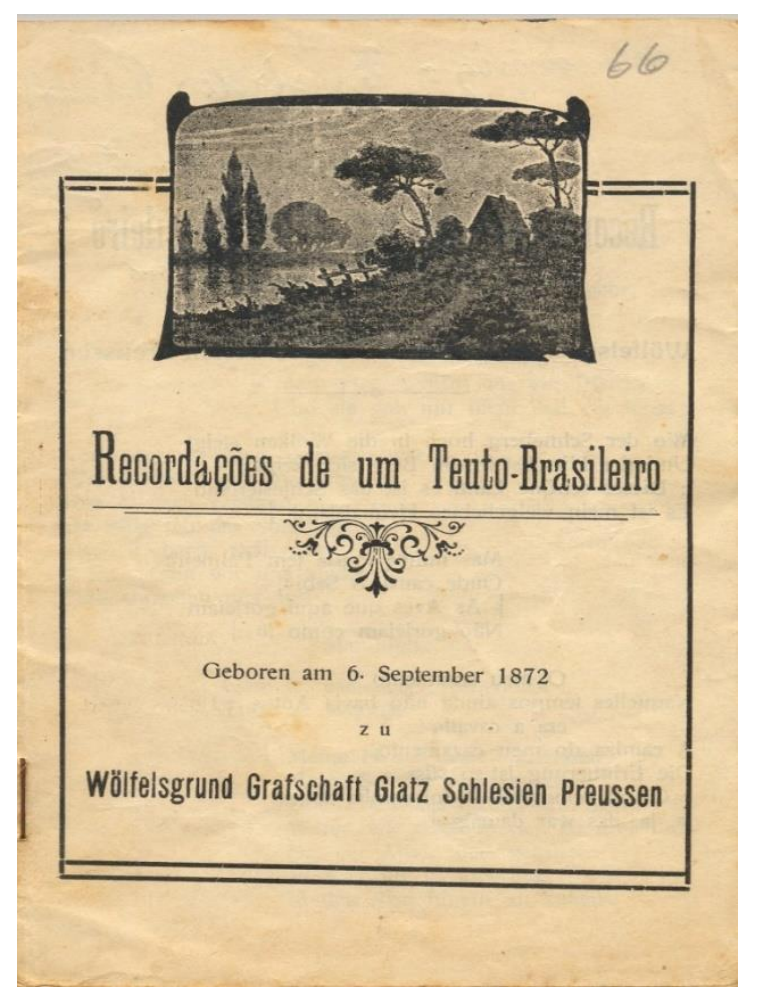

Figura 23

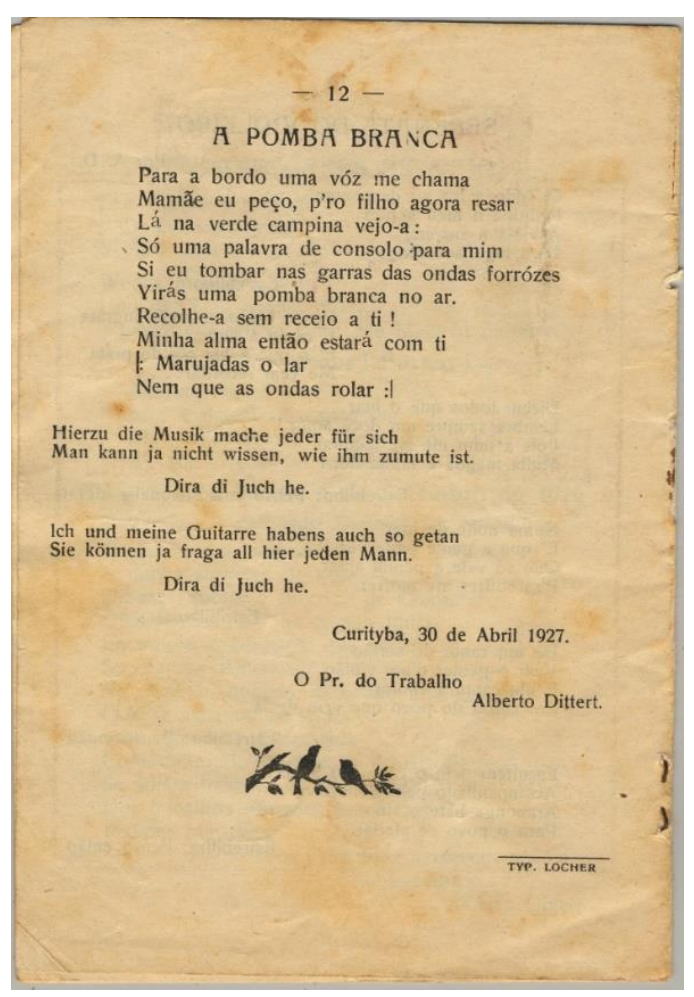

Figura 24 


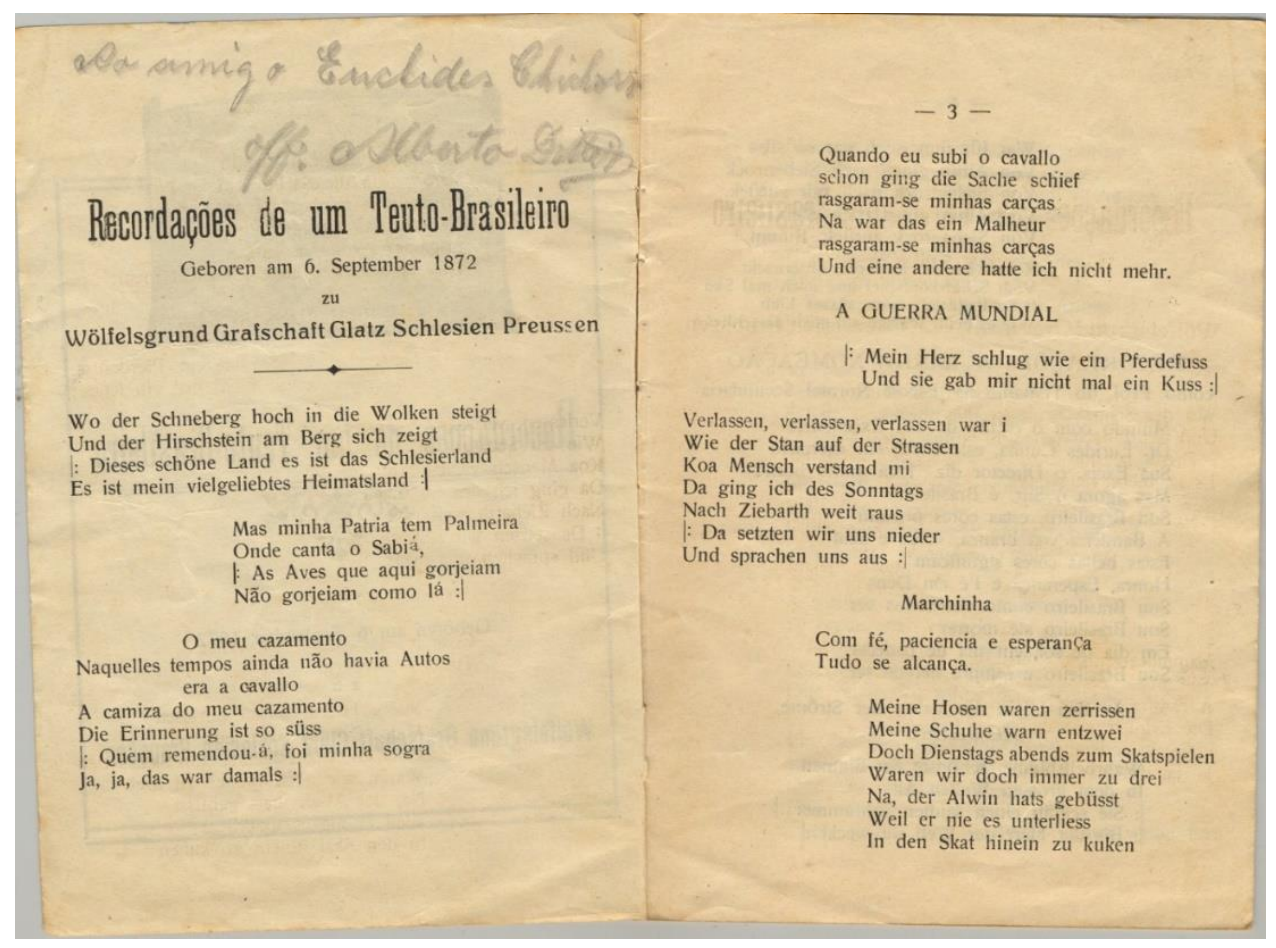

Figura 25 
Figura 26 - Exemplo de fórmula editorial (Col. Mario de Andrade)

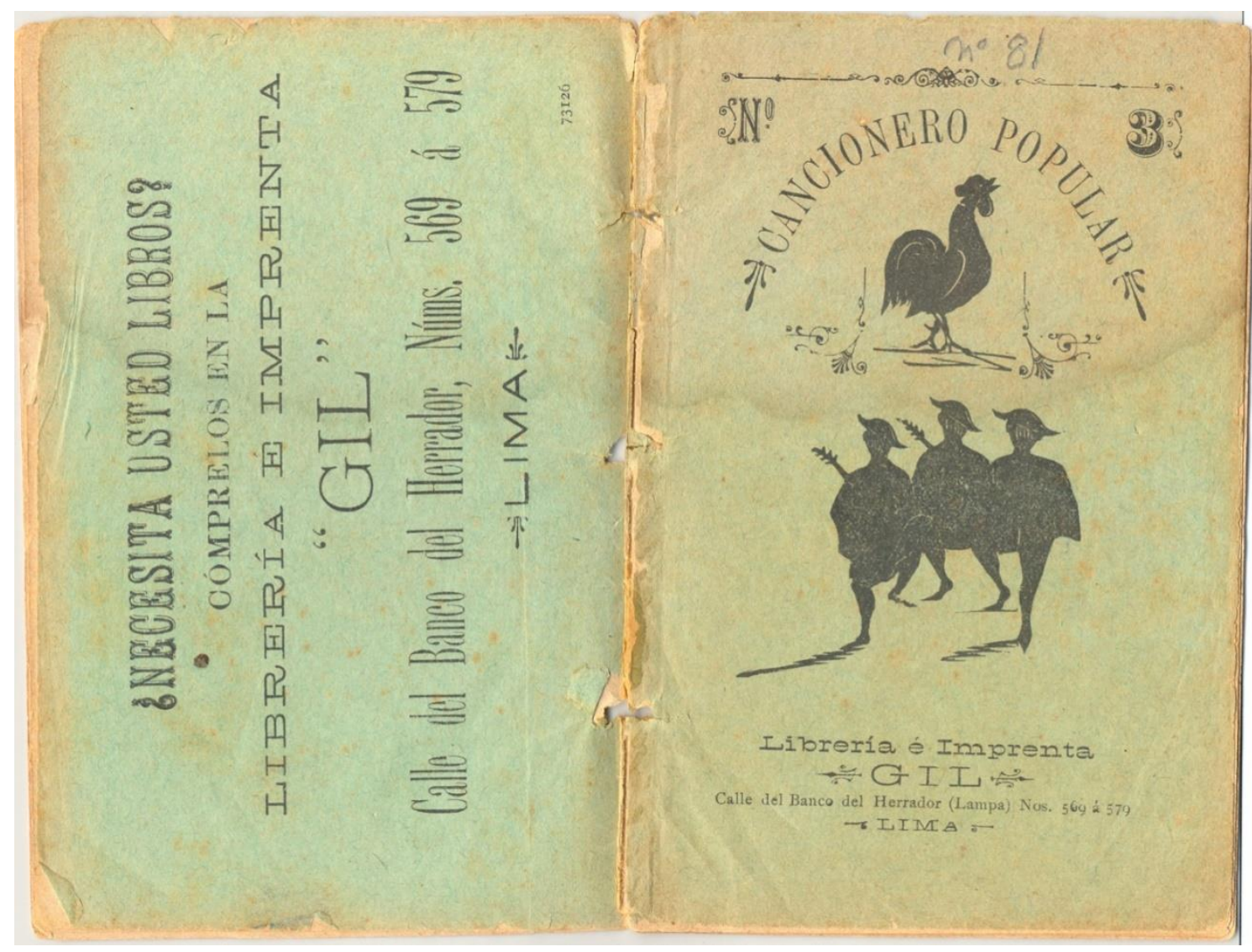

Figura 26 